\title{
Impact of agricultural water management interventions on upstream-downstream trade-offs in the upper Cauvery catchment, southern India: a modelling study*
}

\author{
Pawan S. Wable ${ }^{1}$ | Kaushal K. Garg ${ }^{1}$ | Rajesh Nune ${ }^{1}$ | \\ Akuraju Venkataradha $^{1}$ | Anantha $\mathrm{KH}^{\mathbf{1}}$ | Veena Srinivasan ${ }^{2}$ | Ragab Ragab ${ }^{5}$ | \\ John Rowan ${ }^{4}$ | Virginie Keller ${ }^{5}$ | Pradeep Majumdar ${ }^{3}$ | Gwyn Rees ${ }^{5}$ | \\ Ramesh Singh $^{1}$ | Sreenath Dixit ${ }^{1}$
}

${ }^{1}$ ICRISAT Development Centre, International Crops Research Institute for the Semi-Arid Tropics, Hyderabad, Telangana, India

${ }^{2}$ Ashoka Trust for Research in Ecology and the Environment (ATREE),

Bengaluru, India

${ }^{3}$ Indian Institute of Science (IISc), Bengaluru, India

${ }^{4}$ University of Dundee, Scotland, UK

${ }^{5}$ UK Centre for Ecology and Hydrology,

Wallingford, UK

\section{Correspondence}

Dr Kaushal K. Garg, ICRISAT

Development Centre, International Crops Research Institute for the Semi-Arid Tropics, Hyderabad-502 324, Telangana, India.

Email: k.garg@cgiar.org

Funding information

Ministry of Earth Sciences; Natural

Environment Research Council

\begin{abstract}
The Cauvery basin in southern India is experiencing transboundary issues due to increasing water demand. This study analysed water balance components and the impact of agricultural water management (AWM) interventions in the upper Cauvery catchment of the Cauvery basin. Results showed that the study catchment receives an average of $1280 \mathrm{~mm}$ of annual rainfall. Of this, $29 \%(370 \mathrm{~mm})$ flows downstream, $54 \%(700 \mathrm{~mm})$ contributes to evapotranspiration (ET) and $17 \%(215 \mathrm{~mm})$ contributes to groundwater recharge and surface storage. Rainfall varies from 700 to $5400 \mathrm{~mm}$ and the Western Ghats (mountain pass) are the main source of freshwater generation. The estimated ET in different catchments ranged from 500 to $900 \mathrm{~mm}$ per annum. An increase in the allocation of fresh water supplied by all three reservoirs (Hemavathi, Harangi and KRS) was observed in the canal command areas, from 1450 million cubic metres (MCM) $\mathrm{yr}^{-1}$ in 1971-1980 to $3800 \mathrm{MCM} \mathrm{yr}^{-1}$ in 2001-2010. AWM interventions harvested 140-160 MCM $(13-20 \mathrm{~mm})$ of surface runoff upstream of the upper Cauvery and reduced inflow into the Krishnaraja Sagar reservoir by $2-6 \%$. The study findings are useful for designing and planning suitable water management interventions at basin scale.
\end{abstract}

\section{K E Y W O R D S}

catchment treatment, reservoir inflow, surface runoff, water balance

\section{Résumé}

Le bassin de Cauvery dans le sud de l'Inde connaît des problèmes transfrontaliers en raison de l'augmentation de la demande en eau. Cette étude a analysé les composantes du bilan hydrique et l'impact des interventions de gestion de l'eau agricole (AWM) dans le bassin versant de la Haute

\footnotetext{
* Impact des interventions de gestion de l'eau agricole sur les compromis amont-aval dans le bassin supérieur du Cauvery, dans le sud de l'Inde: une étude de modélisation.
} 
Cauvery du bassin de la Cauvery. Les résultats ont montré que le bassin de l'étude reçoit en moyenne $1280 \mathrm{~mm}$ de précipitations annuelles. Sur ce total, 29\% (370 mm) s'écoulent en aval, 54\% (700 mm) contribuent à l'évapotranspiration (ET) et $17 \%(215 \mathrm{~mm})$ contribuent à la recharge des eaux souterraines et au stockage en surface. Les précipitations varient de 700 à $5400 \mathrm{~mm}$ et les Ghâts occidentaux (col de montagne) sont la principale source de production d'eau douce. L'ET estimée dans différents bassins versants variait de 500 à $900 \mathrm{~mm}$ par an. Une augmentation de l'allocation d'eau douce fournie par les trois réservoirs (Hemavathi, Harangi et KRS) a été observée dans les zones de commande du canal, de 1450 millions de mètres cubes (MCM)/an en 1971-1980 à $3800 \mathrm{MCM} / \mathrm{an}$ en 20012010. Les interventions AWM ont récolté 140-160 MCM (13-20 mm) de ruissellement de surface en amont de l'upper Cauvery et ont réduit l'afflux dans le réservoir Krishnaraja Sagar de 2-6\%. Les résultats de l'étude sont utiles pour concevoir et planifier des interventions appropriées de gestion de l'eau à l'échelle du bassin.

\section{MOTS CLÉS}

bilan hydrique, ruissellement de surface, traitement des bassins versants, afflux de réservoir

\section{INTRODUCTION}

Freshwater availability is essential to ensure food security for an ever-increasing population. Agriculture in rainfed areas is characterized by water scarcity, land degradation, low resource inputs and low productivity. India's net sown area of 141 million ha of which 55\% is rainfed has a cropping intensity of $135 \%$. Agricultural productivity, generally, oscillates between 0.5 and $2.0 \mathrm{t}$ $\mathrm{ha}^{-1}$ with an average of $1.0 \mathrm{t} \mathrm{ha}^{-1}$ (Rockstrom et al., 2009; Wani et al., 2011; Fischer, 2015; Rao et al., 2015; Bhattacharyya et al., 2016; Fischer \& Connor, 2018; Government of India [GoI], 2018; Anantha et al., 2021a). Irrigated land, which constitutes $45 \%$ of the total agricultural area, contributes about $55 \%$ to the total food requirement and consumes almost $70 \%$ of freshwater resources of the country (GoI, 2015; Green et al., 2020).

With limited scope of crop intensification in canal command areas, the focus has shifted towards increasing groundwater $(\mathrm{GW})$ recharge in dryland areas. A number of public welfare programmes such as catchment development, the Mahatma Gandhi National Rural Employment Guarantee Act (MGNREGA) and Pradhan Mantri Krishi Sinchayee Yojana (PMKSY) have been initiated since 1980 as drought mitigation measures (Tiwari et al., 2011; Krishnan \& Balakrishnan, 2012; NITI Aayog, 2017, 2019; Anantha et al., 2021b). Since 1990, about US $\$ 14$ billion have been invested on drought mitigation measures such as field bunds, farm ponds, check dams, terracing and rejuvenating community ponds, also known as agricultural water management (AWM) interventions (Mondal et al., 2020). In situ water-harvesting interventions (e.g. contour/graded bunds) enable improvement in soil moisture availability by enhancing the landscape's infiltration capacity, conserving moisture and controlling soil erosion (Garg et al., 2011; Singh et al., 2014; Garg et al., 2021). Often, larger fields are divided into relatively smaller plots to reduce runoff velocity and harvest a fraction of the runoff across the field bunds. In contrast, ex situ interventions harvest a fraction of surface runoff that drains out from agricultural fields. $E x$ situ interventions such as check dams and farm ponds have a capacity varying from 100 to $10000 \mathrm{~m}^{3}$ (Jain et al., 2007; Singh et al., 2014; Garg et al., 2020a). Despite concerted efforts and the investment India has made in various drought mitigation measures, the impact of AWM interventions on water balance components has not been fully understood (Glendenning \& Vervoort, 2010; Bouma et al., 2011), with some studies focusing on one or two components of land use change and crop production and others focusing on the conceptual framework (Batchelor et al.,, 2003; Shiferaw et al., 2008).

Studies undertaken in the water sector have mostly focused on multi-purpose, large-scale projects (major reservoirs) to address food security 
(Goyal \& Surampalli, 2018; Bhanja \& Mukherjee, 2019); mapping water use efficiency (Garg et al., 2012b); crop intensification (Jayne et al., 2004; Heller et al., 2012; Pellegrini \& Fernández, 2018); and analysing socioeconomic impacts (Bhave et al., 2018; Whitehead et al., 2018); migration (Tilt et al., 2009; Deshingkar, 2012; Weinthal et al., 2015); and transboundary issues (Sood \& Mathukumalli, 2011; UNEPDHI Centre on Water and Environment, 2016). To the best of the authors' knowledge, the impact of AWM interventions on hydrological processes at catchment/basin scale has not been investigated thoroughly. However, a few studies have analysed their impact at micro $\left(<10 \mathrm{~km}^{2}\right)$ and meso $\left(10-100 \mathrm{~km}^{2}\right)$ scale catchment hydrology either by comparing paired catchments (Zégre et al., 2010; Singh et al., 2014; Sultan et al., 2018) or before and after catchment treatment impacts (Huang \& Zhang, 2004; Lodha \& Gosain, 2007; Nyssen et al., 2009; Garg et al., 2011; Mekonen \& Tesfahunegn, 2011). The focus of all these studies was to quantify the impact of catchment interventions on surface runoff, agricultural productivity and upstream-downstream trade-offs. The knowledge generated from micro- and meso-scale catchments was very important, but may not directly be applicable to catchment- or basin-scale decision making due to the difference in scale (Vinogradov et al., 2011; Gentine et al., 2012).

The Soil and Water Assessment Tool (SWAT) is a widely used hydrological model that uses a geographic information system (GIS) interface to capture landscape variability and runs on a daily time step. SWAT has been used to simulate water resource assessment (Krysanova \& White, 2015; Gupta et al., 2020); map agriculture water productivity (Garg et al., 2012b; Thokal et al., 2015; Ahmadzadeh et al., 2016); optimize reservoir operation (Wu \& Chen, 2012; Anand et al., 2018); study the impact of land use and management practices (Krysanova \& White, 2015; Jodar-Abellan et al., 2019); study climate change effects (Narsimlu et al., 2013; Uniyalet al., 2015; Marin et al., 2020); and quantify various ecosystem services (Dile et al., 2016a, 2016b; Lee et al., 2018). It has also been used to analyse upstream-downstream water balance at meso- (Dile et al., 2016a, 2016b), catchment and basin scales (Masih et al., 2011).

SWAT can capture the hydrological response to AWM interventions and could be customized for a micro-scale community catchment to a large-scale catchment depending on data availability (Glavan \& Pintar, 2012). It has been used to evaluate the impact of soil conservation measures on runoff and sediment transport (Betrie et al., 2011; Dile et al., 2013; Dile et al., 2016a, 2016b; Woldesenbet et al., 2017, 2018;
Worku et al., 2017; Mekonnen et al., 2018; Horan et al., 2021). It also allows estimation of the integrated impacts of changes in land use-land cover (LULC) and biophysical factors under different land management interventions (Arnold et al., 2012; Berihun et al., 2020).

This study aimed to analyse the impact of various AWM interventions on downstream water availability in the upper Cauvery sub-basin of southern India. The Cauvery basin experiences severe water scarcity for up to 8 months a year, affecting over 35 million people (Ferdin et al., 2010; Hoekstra et al., 2012). The specific objectives of the study are: (i) to understand the water utilization pattern in major reservoirs of the upper Cauvery catchment; (ii) to analyse water balance components of the entire catchment; (iii) to analyse the impact of AWM interventions on reservoir inflow into the Krishnaraja Sagar (KRS).

\section{2 | MATERIALS AND METHODS}

\section{$2.1 \quad$ Study area}

The Cauvery catchment is one of the largest basins in southern India with a catchment area of $81155 \mathrm{~km}^{2}$. The river flows through the states of Karnataka (42.2\%), Tamil Nadu (54\%) Kerala (3.5\%) and Puducherry (0.2\%) (India-WRIS WebGIS, 2014; Horan et al., 2021). The basin faces water stress and a number of socioeconomic and political challenges. The availability of fresh water in the basin has declined due to increasing population, crop intensification, industrialization and fast urban growth over the last two decades. Competing demands for water from the agricultural, domestic and industrial sectors have exacerbated the situation. The agriculture sector is one of the largest consumers of fresh water in this basin, with agricultural land being the major land cover type $(>50 \%)$. The food security and livelihood of millions of farmers mainly depend on freshwater availability (both surface and groundwater resources). The catchment is characterized by large spatial variability in terms of rainfall, land use, topography, soil type and various land management factors (Sreelash et al., 2020).

The upper Cauvery catchment was chosen to study the impact of AWM interventions because it is situated in the uppermost part of the basin and is relatively independent in terms of hydrological processes. The catchment covers $10619 \mathrm{~km}^{2}, \sim 13 \%$ of the total basin. The entire upper Cauvery catchment lies in Karnataka, covering parts of Chikkamagaluru, Kodagu, Hassan, Mandya and Mysore districts (Figure 1). Average annual rainfall in the 


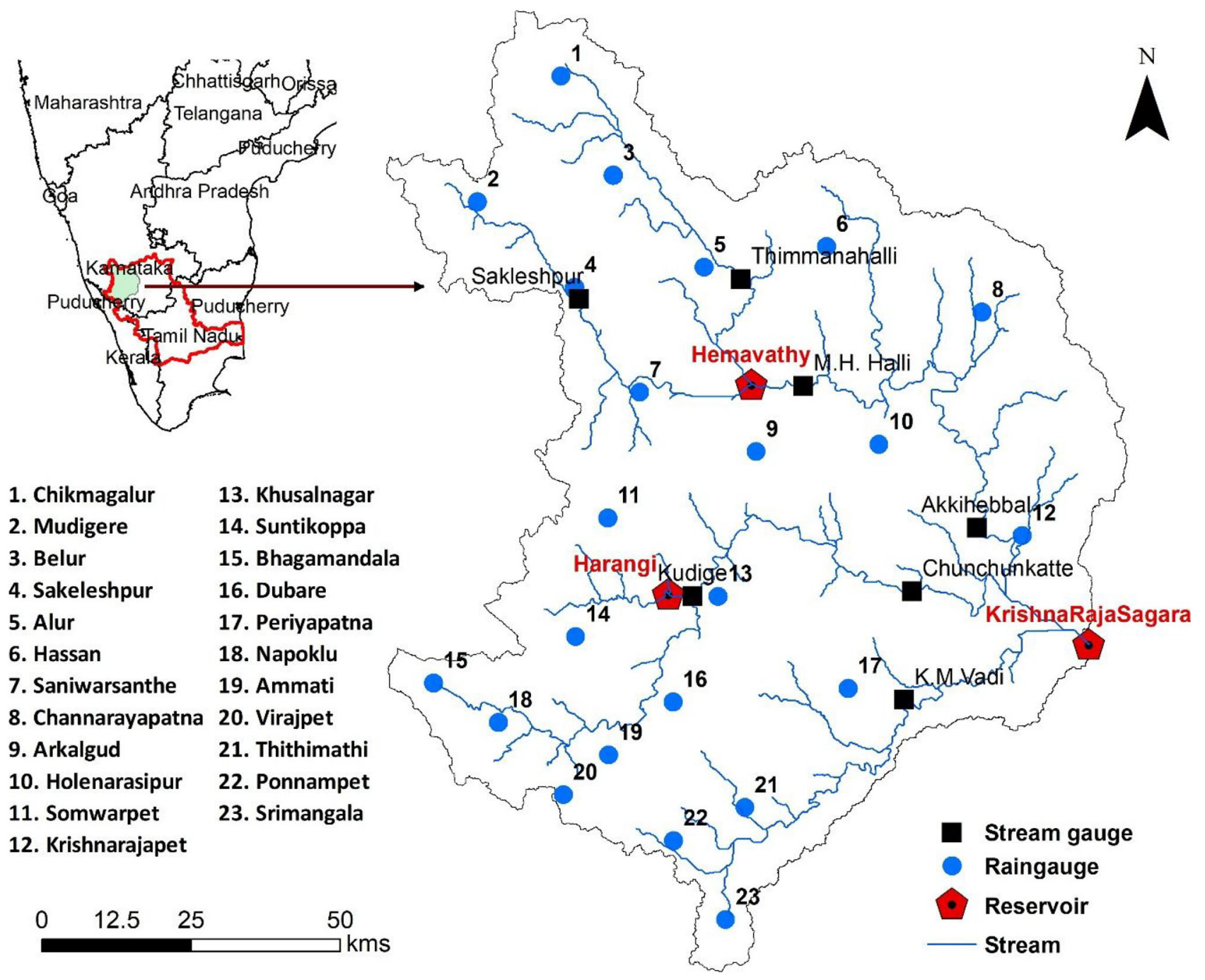

F I G U RE 1 Upper Cauvery sub-basin, major streams, location of rain gauges, stream gauges and major reservoirs in the catchment

catchment is $1280 \mathrm{~mm}$ with a huge spatial variability of 600-5400 $\mathrm{mm}$. The catchment includes several tributaries including the Hemavathy and Laxmanthirtha, which join the Cauvery river and flow into the KRS dam (outlet of the study basin). The maximum storage capacity of the KRS reservoir is 1280 million cubic metres (MCM). There are two other major reservoirs in the upper Cauvery basin, the Hemavathy and Harangi, with a maximum storage capacity of 927 and 229 MCM, respectively (Figure 1).

\subsection{Data collection}

Figure 2 describes the methodological approach followed based on the study's objectives. The study first analysed the hydrology of the Hemavathy, Harangi and KRS reservoirs using long-term measured data on inflow, utilization in agriculture (canal command) and release into downstream rivers (section 3.2). Water balance components of the upper Cauvery catchment were estimated using SWAT simulation (sections 3.3 and 3.4). Using a calibrated model set-up, the impact of AWM interventions on the KRS reservoir was analysed and further projected by describing two future scenarios in 2030 and 2040 (section 3.5).

The daily rainfall data of 23 rain gauge stations for the period 1979-2013 (Figure 1) were collected along with daily maximum and minimum temperature gridded data at the scale of $0.125^{\circ}$ from the India Meteorological Department (IMD). Daily relative humidity, sunshine hours and wind speed for three climate stations (Bengaluru, Thrissur and Coimbatore) were collected for the same period. The Digital Elevation Model (DEM) of the study area at $90 \mathrm{~m}$ spatial resolution was downloaded 


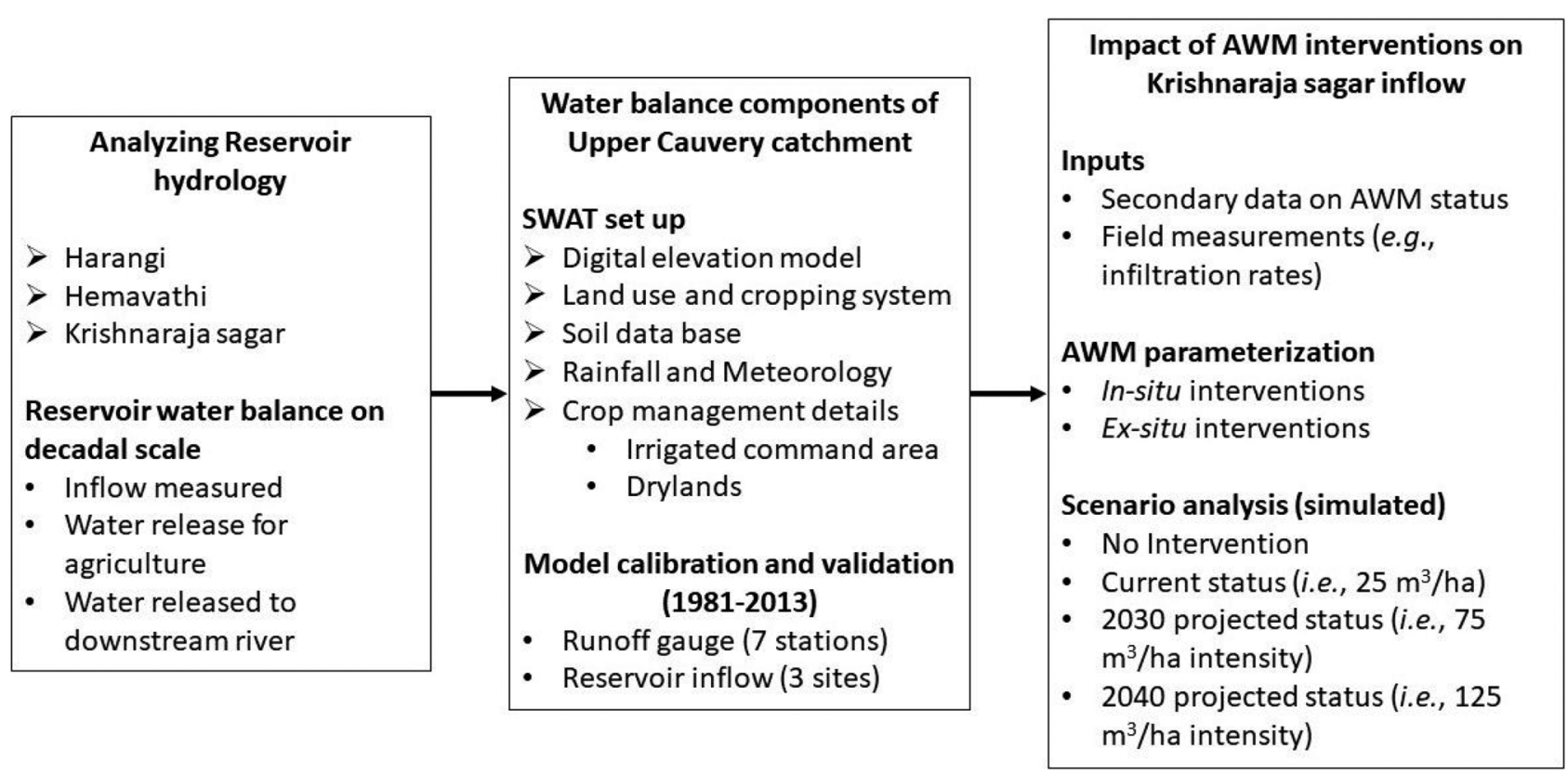

FIGURE 2 Schema of the adopted methodology

from the CGIAR Consortium for Spatial Information (http://srtm.csi.cgiar.org). The land use/land cover (LULC) map of the study area at a 1:250 000 scale was collected from the National Remote Sensing Centre (NRSC) for the year 2016. Crop statistics data were obtained from the government platform (https://data. gov.in/) and web-based land use statistics (http://aps.dac. gov.in/LUS/Index.htm). The soil map of the study area was acquired from the National Bureau of Soil Survey and Land Use Planning (NBSS\&LUP). The study also used the soil database developed by the International Crops Research Institute for the Semi-Arid Tropics (ICRISAT) during 2005 and 2019 for previous studies in Karnataka (Wani et al., 2017; Garg et al., 2020b; Anantha et al., 2021a).

The daily discharge data from seven gauge locations (Sakelshpur, Akkihebbal, MH Halli, Akkihebbal, Kudige, Chuchunkatte and KM Vadi) were obtained from IndiaWRIS WebGIS (http://www.india-wris.nrsc.gov.in/). Information on monthly storage, inflows and outflows of three major reservoirs between 1970 and 2010 was obtained from the Command Area Development Authority (CADA) of Hassan, Kodagu and Mysore districts. A map of the irrigated area (command area) under these reservoirs was obtained from the National Water Development Agency (NWDA), Bengaluru, India. Data on the number and type of structures constructed, total treated area along with investments between 2006 and 2012 were sought from catchment development department, Bengaluru.

\section{3 | Model description}

SWAT is a semi-process-based model that operates on a daily time step. The study catchment was divided into nine major land uses/land covers (Figure 3 and Table 1 (a)). In the study area, $51 \%$ of the total geographical area is under agriculture, $31 \%$ forest, $11 \%$ fallow/shrubland and $7 \%$ comprises settlement, water bodies and other uses/covers. The land use inputs were kept the same for the study period (1981-2013) as there was no significant change found from one to another land use between this period (NWDA, 2019); however, within agricultural land, cropping intensity increased over the period. There are two major soil types: clay $\left(6395 \mathrm{~km}^{2}, 58 \%\right)$ and clay loam $\left(4551 \mathrm{~km}^{2}, 42 \%\right)$. The entire catchment was further classified into three land slopes: $0-5 \%$ covering $6415 \mathrm{~km}^{2}$ (59\%), 5-10\% covering $2716 \mathrm{~km}^{2}(25 \%)$ and greater than $10 \%$ covering $1816 \mathrm{~km}^{2}$ (16\%). With all these combinations, the entire study area was divided into 129 mesoscale subcatchments and 4432 hydrological response units (HRUs). The daily rainfall, maximum and minimum temperatures, relative humidity, wind speed and solar radiation between 1981 and 2013 were provided as inputs to the model. Table 1(a) shows the major land use classes in the study area and crop management details provided as inputs to the model. Two major upstream reservoirs (Hemavathy and Harangi) were modelled by creating the reservoir nodes at the respective sites. Their maximum storage capacity, water spread area and the volume required to fill the emergency spillway were 


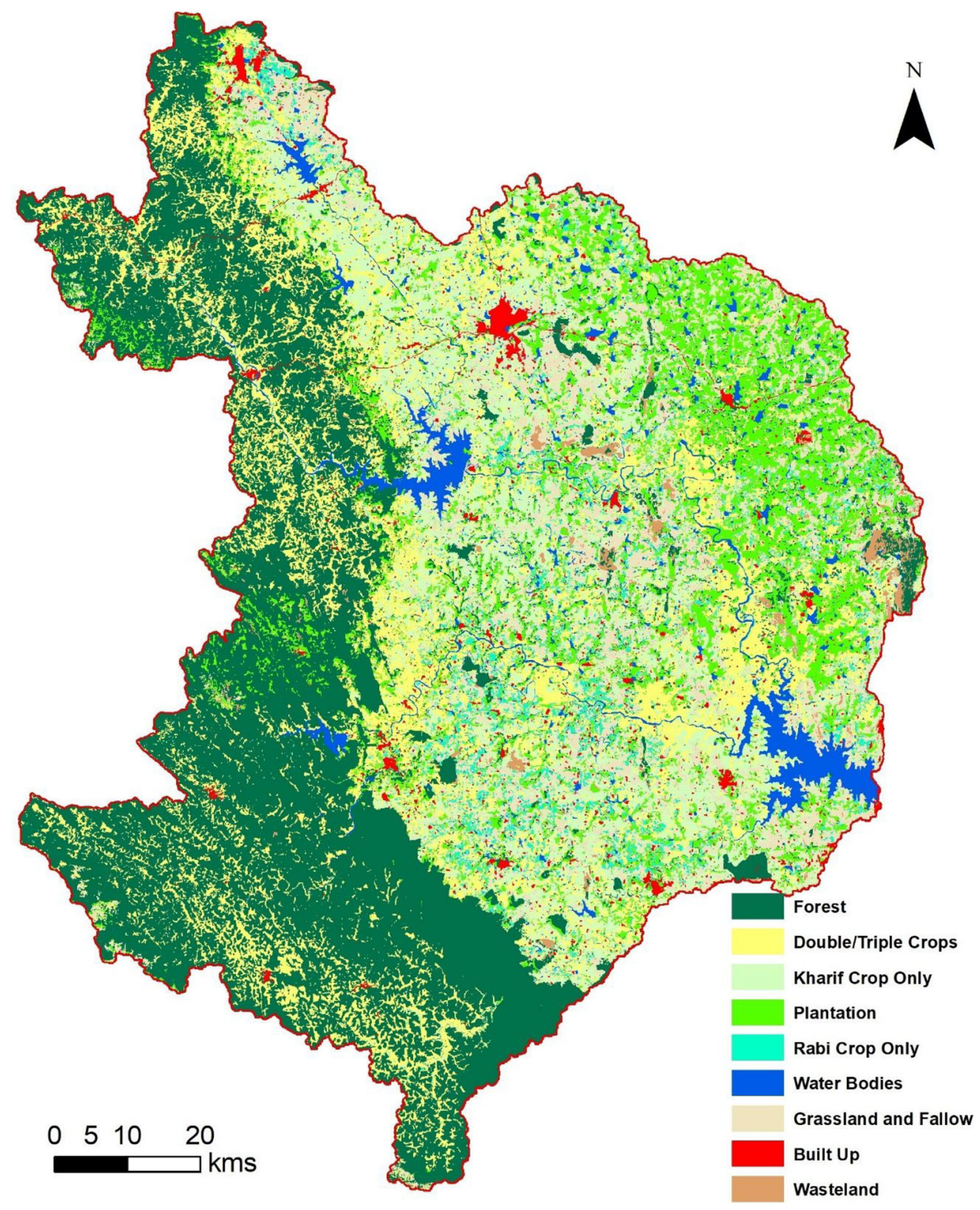

FIG URE 3 Land use land cover (LULC) map of the upper Cauvery catchment (2016-17)

T A B LE 1 (a) Land use/land cover (LULC) statistics and crop season

\begin{tabular}{llclll} 
Major class & LULC & Area $\mathbf{( \mathbf { k m } ^ { 2 } )}$ & Area (\%) & Modelled as & Period \\
\hline Built-up area & Built up & 210 & 2 & Settlement & - \\
Agriculture & Rainy season crops & 1300 & 12 & Sorghum, rice & 15 Jun-15 Oct \\
\hline Agriculture & Post-rainy season crops & 441 & 4 & Sorghum & 15 Nov-30 Mar \\
\hline Agriculture & Double/triple crops & 2443 & 23 & Sorghum, rice & 15 Jun-15 Oct, 1 Jan-31 Apr \\
\hline Wasteland & Current fallow & 1151 & 11 & Rangeland & Perennial \\
\hline Horticulture & Plantation crops & 1286 & 12 & Coconut & Perennial \\
\hline Forest & Forest & 3391 & 31 & Forest & Perennial \\
\hline Wasteland & Wasteland & 119 & 1 & Rangeland & Perennial \\
\hline Water & Water & 427 & 4 & Water & - \\
\hline
\end{tabular}


provided from actual records. Delineated catchments and HRUs belonging to the canal command areas of the respective reservoirs were demarcated and assigned as sources of irrigation. Rice was cultivated during both rainy (kharif) and post-rainy (rabi) seasons in these HRUs. An auto-irrigation rule was assigned to the model for irrigation management. Initializing auto-irrigation enables the automatic continuation of irrigation during the crop period whenever soil moisture levels are depleted below defined limits (Hao et al., 2015; Vories et al., 2017; Chen et al., 2020).

Sorghum was grown during the rainy season (rice: July to November; sorghum: July to 15 November; and vegetables: July to December) and post-rainy season (rice and vegetables: January to April) as per LULC other than command areas. During the post-rainy period, crops were supported with supplemental irrigation and the groundwater aquifer was mapped as a source of irrigation in the drylands. Details such as date of sowing, harvesting, tillage operations and fertilizer application were provided based on farmers' interviews.

Table 1(b) shows the input values provided for the model and their parameterization. We found that available water content (field capacity-permanent wilting point) and soil depth are the most sensitive soil physical parameters. Soil biophysical data retrieved from
NBSS\&LUP and ICRISAT were used as direct input. Sensitive parameters such as curve number, REVAP_MN, GWQMN and GW_DELAY that control hydrological processes were used to calibrate the model.

Reservoir nodes were created in different microcatchments to represent the AWM interventions. Based on the data collected from the Department of Agriculture, Government of Karnataka, equivalent waterharvesting capacities were assigned both for in situ and ex situ interventions. The main differences between in situ and ex situ interventions are the surface area, depth of water harvesting and infiltration rates. Field bunds are common in situ interventions that harvest runoff water to a maximum height of $0.2-0.4 \mathrm{~m}$, generally across the slope. So the water spread area is relatively greater than in farm ponds that are excavated pits of 2-3 $\mathrm{m}$ depth to harvest surface runoff (Figure 4). The water spread area to harvest $1 \mathrm{~m}^{3}$ of runoff water through in situ and ex situ interventions are 5-10 and $0.5-1.0 \mathrm{~m}^{2}$, respectively. In addition, water infiltration rates of $4 \mathrm{~mm} \mathrm{~h}^{-1}$ in farm ponds and $12 \mathrm{~mm} \mathrm{~h}^{-1}$ in field bunds were measured (based on 10 locations) at Lakumanahalli micro-catchment in Chikkamagaluru district (Table 2(a)).

The model was run on a daily time step between 1981 and 2013. It was calibrated by comparing simulated

T A B LE 1 (b) Model inputs and calibration parameters

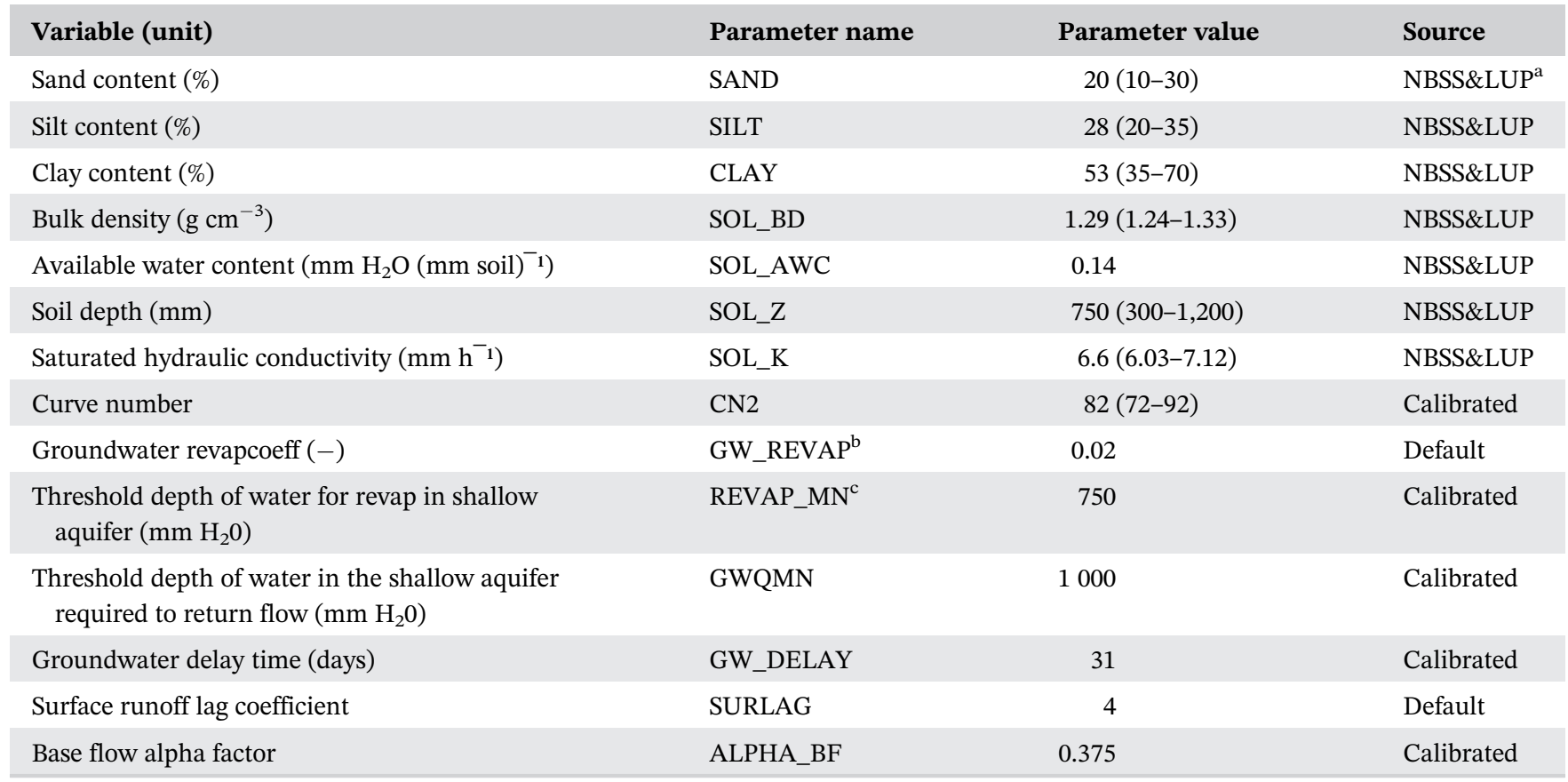

${ }^{a}$ NBSS\&LUP: National Bureau of soil Survey and Land Use Planning.

${ }^{\mathrm{b}}$ Groundwater revapcoeff: Water may move from the shallow aquifer into the overlying unsaturated zone. As GW_REVAP approaches 0, movement of water from the shallow aquifer to the root zone is restricted. As GW_REVAP approaches 1, the rate of transfer from the shallow aquifer to the root zone approaches the rate of potential evapotranspiration.

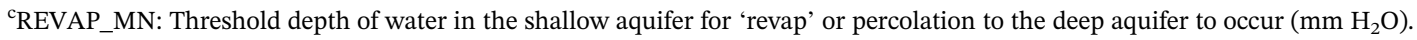


(a) Field bund

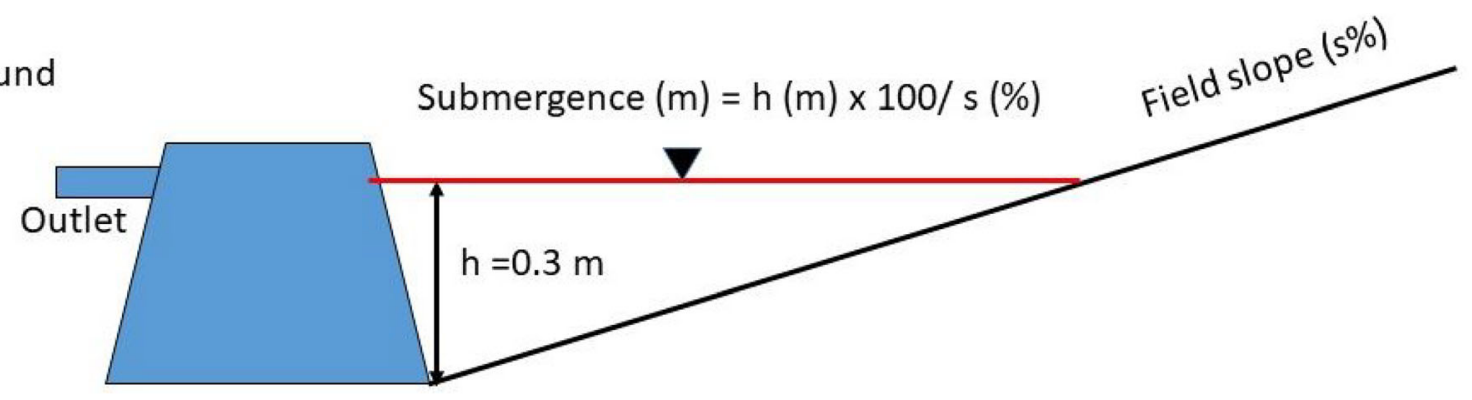

(b) Farm pond

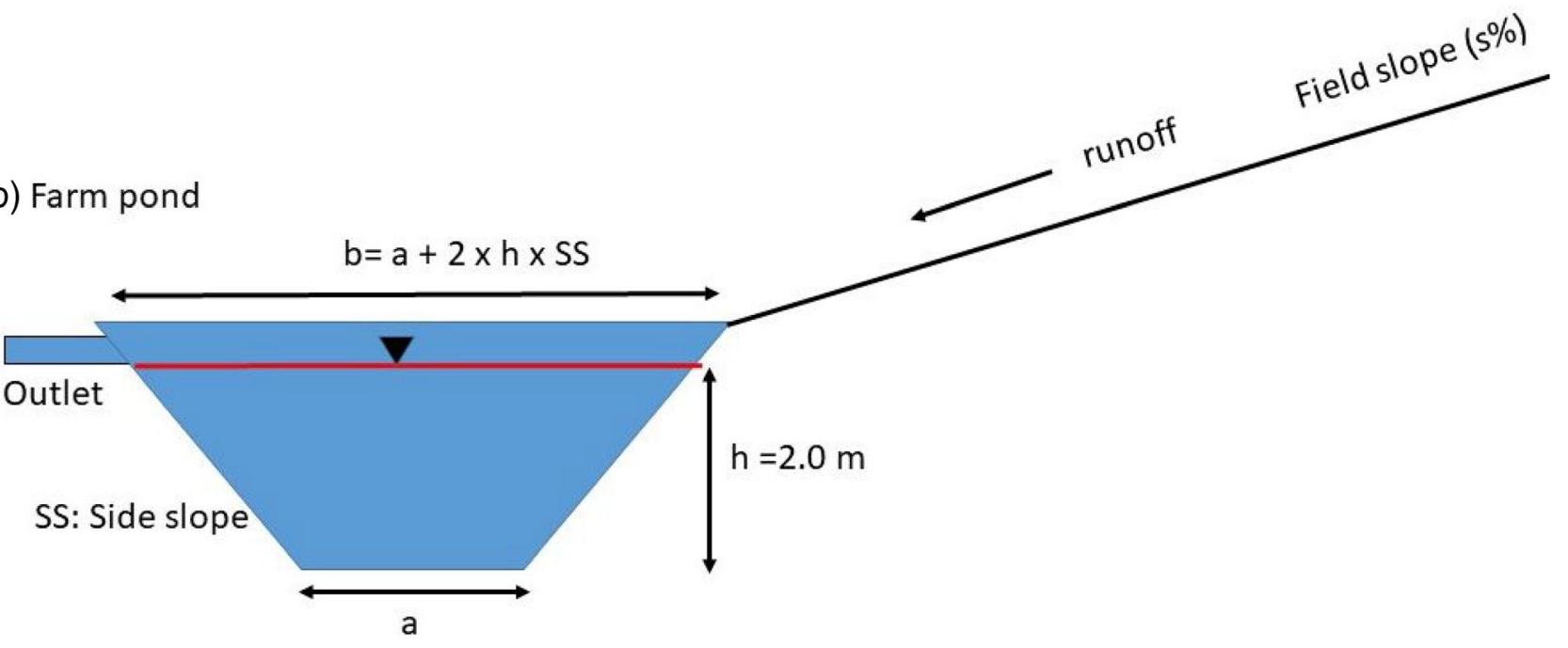

F I G U RE 4 Conceptual diagram of (a) field bund (in situ) and (b) farm pond (ex situ). Figures are not to scale

T A B LE 2 (a) Parameterization of in situ and ex situ AWM interventions

\begin{tabular}{llll} 
Parameters & Parameter & Ex situ interventions & In situ interventions \\
\hline $\begin{array}{l}\text { Name of structure } \\
\text { Maximum water harvesting depth }(\mathrm{m})\end{array}$ & Depth of water $(\mathrm{h})$ & 2.0 & Field bunds \\
\hline $\begin{array}{l}\text { Cross section }\left(\mathrm{m}^{2}\right) \text {. Refer to Figure } 4 \\
\begin{array}{l}\text { Hydraulic conductivity of the reservoir bottom } \\
\left(\mathrm{mm} \mathrm{h} \mathrm{h}^{-1}\right)\end{array}\end{array}$ & AREA & 14 & 0.3 \\
\hline Water harvesting capacity $\left(\mathrm{m}^{3}\right)$ & VOL & 4 & $2.25^{\mathrm{a}}$ \\
\hline
\end{tabular}

${ }^{\mathrm{a}}$ Land slope $=2 \%$.

${ }^{\mathrm{b}}$ Field bunds of 0.4 ha field ( 1 acre landholding $)=40 \mathrm{~m}$.

surface runoff with observed flow data at seven gauging sites and inflows measured at three reservoir locations. The model's performance was evaluated using three statistical indicators: root mean square error (RMSE), Nash-Sutcliffe efficiency (NSE), and coefficient of determination $\left(R^{2}\right)$. A low RMSE value indicates better model performance. The NSE values ranged from $-\infty$ to 1 , with values less than or very close to 0 indicating 'unacceptable' or 'poor' model performance and values equal to 1 indicating 'perfect performance'. $R^{2}$ ranged from 0 to 1 , with a value of 0 indicating no correlation between simulated and observed values.
Scenario generation. Four land management scenarios were developed to analyse the impact of AWM interventions on inflows into the KRS reservoir:

- No intervention scenario. This scenario represents the control condition. All the reservoir nodes are removed from the model set-up (those that captured in situ and ex situ interventions). This scenario does not exclude the ancient tank system and Hemavathy and Harangi reservoirs as these are integral parts of the catchment;

- Current stage (2020). This is the current SWAT set-up calibrated with existing rainwater-harvesting 
interventions. Investments in in situ and ex situ interventions were found to be in the ratio of $70: 30$ and current AWM density (intervention retention capacity per ha) implemented in drylands was $20-25 \mathrm{~m}^{3} \mathrm{ha}^{-1}$.

- Future scenario 2030. Current structure density in the study basin is $25 \mathrm{~m}^{3} \mathrm{ha}^{-1}$. The Government of Karnataka is emphasizing the construction of farm ponds and similar interventions with a minimum storage capacity of $150 \mathrm{~m}^{3}$ on smallholder farmers' fields (less than 2.0 ha of farmland) under the farm pond scheme (Government of Karnataka [GoK], 2014). Such interventions are likely to lead to an additional $50 \mathrm{~m}^{3} \mathrm{ha}^{-1}$ retention in one decade, thereby increasing rainwaterharvesting capacity to $75 \mathrm{~m}^{3} \mathrm{ha}^{-1}$ which was considered in the simulation;

- Future scenario 2040. Further, it is assumed that harvesting intensity in the study area will reach $125 \mathrm{~m}^{3} \mathrm{ha}^{-1}$ under this scenario.

Model calibration. Table 2(b) shows model inputs for developing no-intervention, 2030 and 2040 scenarios. The model was calibrated at 10 sites (7 runoff gauges and 3 reservoirs) using the periods shown in Table 3. Following the successful calibration, the model was run with the above mentioned scenarios.

\section{3 | RESULTS}

\section{1 | Rainfall characterization}

Variability of measured rainfall from 23 stations between 1979 and 2013 is presented on a yearly timescale in Figures 5(a) and (b). Of the 23 stations, average annual rainfall at 10 of them was less than $1000 \mathrm{~mm}$; at 5 stations between 1000 and $2000 \mathrm{~mm}$; at 7 stations between 2000 and $3000 \mathrm{~mm}$ and at 1 station more than $4000 \mathrm{~mm}$. Bhagamandala in Kodagu District (station no. 15) received the highest annual average rainfall $(5400 \mathrm{~mm})$ and Channarayapatna in Hassan District (station no. 8) received the lowest $(720 \mathrm{~mm})$. However, there was huge a variation in the temporal scale, as shown in Figure 5 (b). Overall, the average annual rainfall of the study area was $1280 \mathrm{~mm}$.

\section{2 | Decadal analysis of inflow, water uses and downstream release in major reservoirs}

Krishnaraja Sagar, Hemavathy and Harangi reservoirs located in the catchment have been functional since 1934, 1979 and 1982, respectively. A storage capacity of about 1240 MCM was created with the Hemavathy and Harangi reservoirs during 1979-1982. The measured actual inflows and major outflows (canal and river releases) of the three reservoirs were analysed for four decades: 1971-1980, 1981-1990, 1991-2000 and 20012010. The average decadal inflows into the KRS reservoir fell by a third from 5500 to $3500 \mathrm{MCM} \mathrm{yr}^{-1}$ during 19811990 compared to 1971-1980 due to the construction of two upstream reservoirs (Harangi and Hemavathy). Inflows into the KRS reservoir during 1991-2000 and 2001-2010 were 4200 and $4000 \mathrm{MCM} \mathrm{yr}^{-1}$, respectively. Inflows into the Harangi reservoir over the last three decades were 900-1000 $\mathrm{MCM} \mathrm{yr}^{-}$, and in the Hemavathy reservoir 2200-2500 $\mathrm{MCM} \mathrm{yr}^{-1}$ (Figure 6(a)). Not much inter-decadal variation in inflows was observed as they are located on the most upstream side and receive runoff from the Western Ghats region that has least anthropogenic interference.

The annual average canal releases of the KRS, Hemavathy, and Harangi reservoirs for four decades were 47, 55 and $61 \%$ of total inflow in the KRS, Harangi and Hemavaty and are presented in Figure 6(b). The canal command area of the Harangi reservoir is located in the upper Cauvery catchment whereas $85 \%$ of the Hemavathy canal command area is located in the study

T A B LE 2 (b ) Model inputs to capture agriculture water management scenarios

\begin{tabular}{|c|c|c|c|c|c|}
\hline \multirow[b]{2}{*}{ Scenario/time period } & \multirow[b]{2}{*}{ Unit } & \multirow{2}{*}{$\begin{array}{l}\text { No intervention } \\
\text { stage }\end{array}$} & \multirow{2}{*}{$\begin{array}{l}\begin{array}{l}\text { Current } \\
\text { stage }\end{array} \\
2020\end{array}$} & \multirow{2}{*}{$\begin{array}{l}\text { Future } \\
\text { stage } 1 \\
\text { In } 2030\end{array}$} & \multirow{2}{*}{$\begin{array}{l}\text { Future } \\
\text { stage } 2\end{array}$} \\
\hline & & & & & \\
\hline Total treated area with in situ intervention & $\mathrm{km}^{2}$ & 0 & 3350 & 3350 & 3350 \\
\hline Total treated area with ex situ intervention & $\mathrm{km}^{2}$ & 0 & 2782 & 2782 & 2782 \\
\hline $\begin{array}{l}\text { Model parameter (RES_VOL) under ex situ } \\
\text { intervention }^{\text {a }}\end{array}$ & $\mathrm{MCM}$ & 0 & 4 & 13 & 22 \\
\hline
\end{tabular}

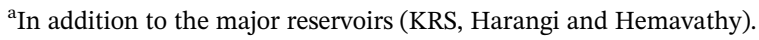



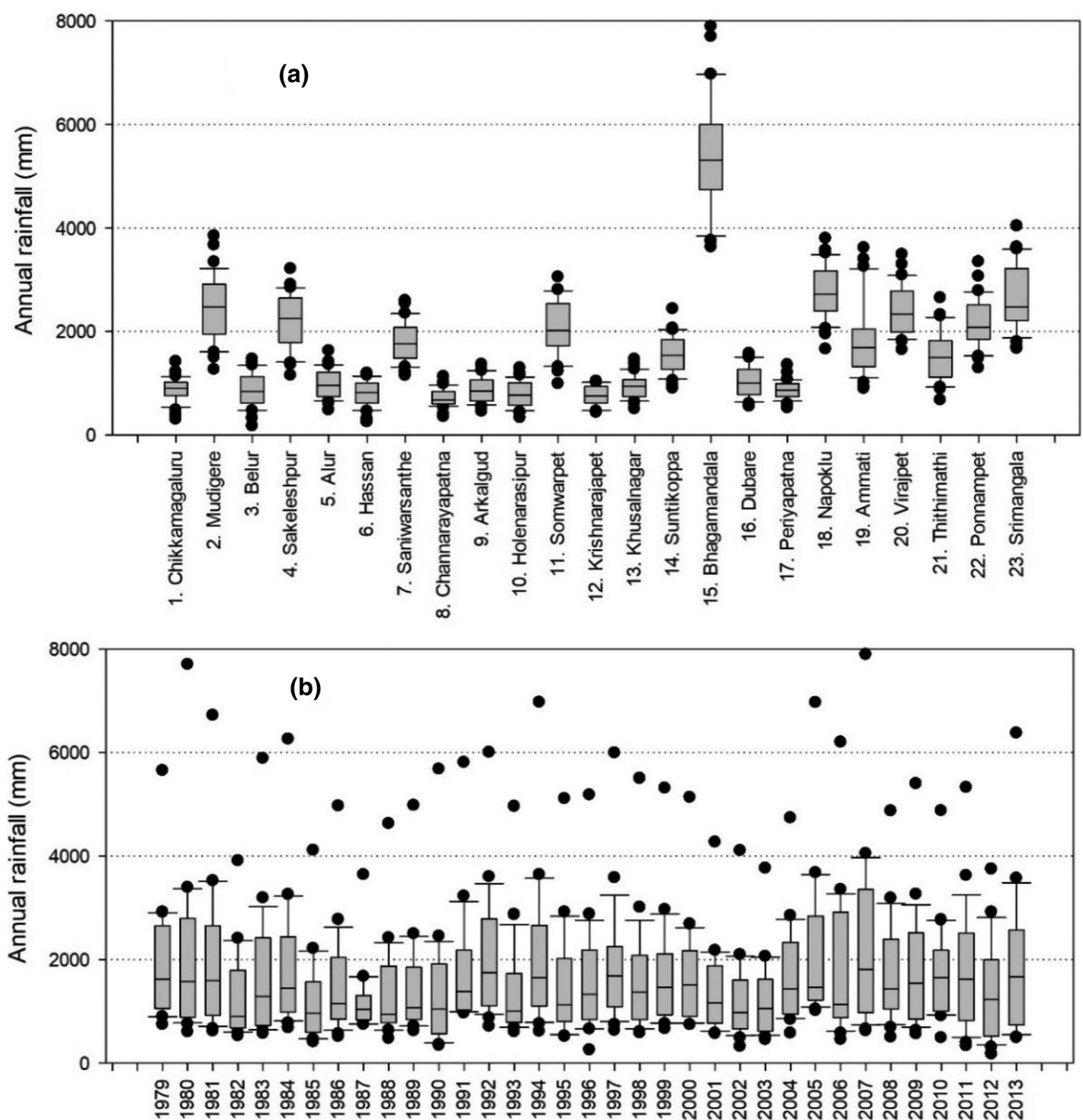

F I G U RE 5 (a) Spatial variation and (b) temporal variation in annual rainfall at 23 rain gauge stations of the upper Cauvery sub-basin over 35 years (1979-2013)

catchment and the rest lies outside the basin. In contrast, the canal command area of the KRS reservoir lies completely outside the upper Cauvery catchment. An increasing trend towards the release of canal water from all three reservoirs has been observed. Total surface water utilization (canal water release) for agriculture was 1450 MCM in 1971-1980, 2500 MCM in 1981-1990, 3500 MCM in 1991-2000 and 3800 MCM in 2001-2010. Of the total inflow received into the KRS reservoir, water released for the canal command area increased from $27 \%$ (of total inflow) in 1971-1980 to $47 \%$ in 2001-2010. Similarly, water utilization in agriculture (released to the canal command area) in the Harangi reservoir increased from $30 \%$ in 1981-1990 to 55\% in 2001-2010, respectively and in the Hemavathy reservoir it increased from $26 \%$ in 1981-1990 to $61 \%$ in 2001-2010.

Average annual reservoir releases to downstream locations for all four decades are presented in Figure 6(c). With reduced inflows and increased canal water release, downstream release from the KRS reservoir declined by 
F I G URE 6 Decade-wise analysis of the measured (a) water inflows into reservoirs, (b) release from reservoirs into canals and (c) release from reservoirs into river of the Harangi, Hemavathy and KRS reservoirs (label values indicate percentage of total inflow)

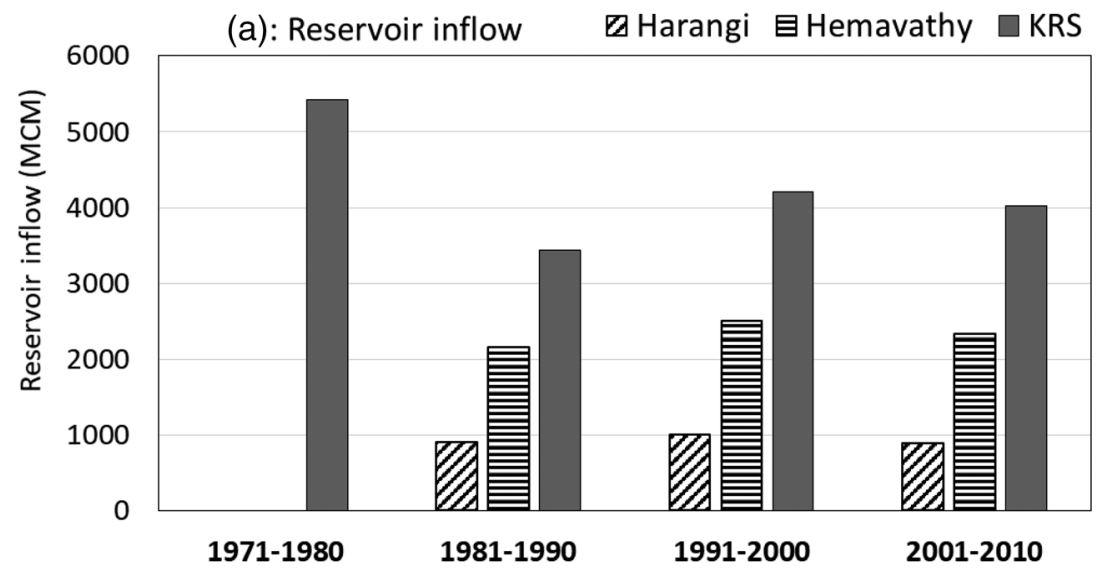

(b): Canal release

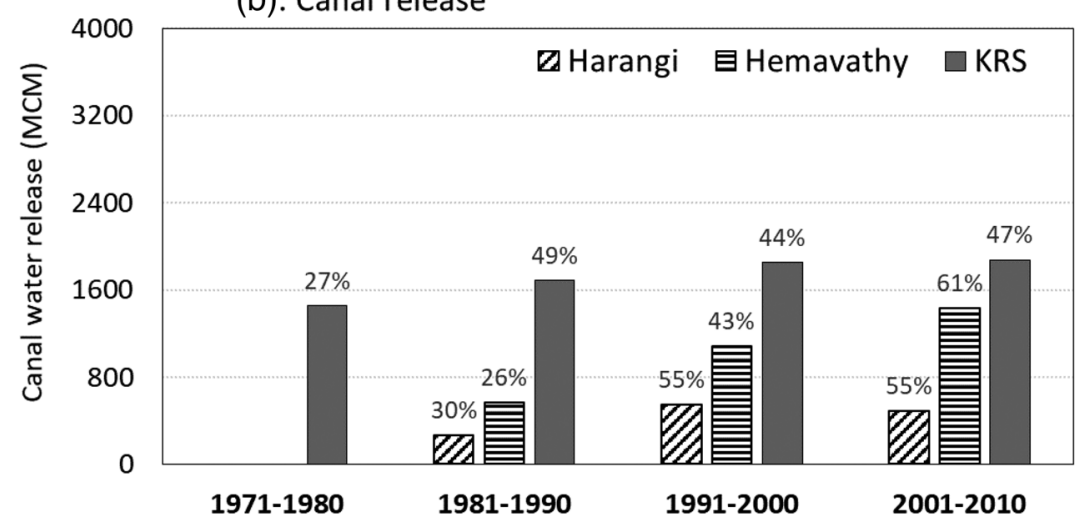

(c): Water release to downstream

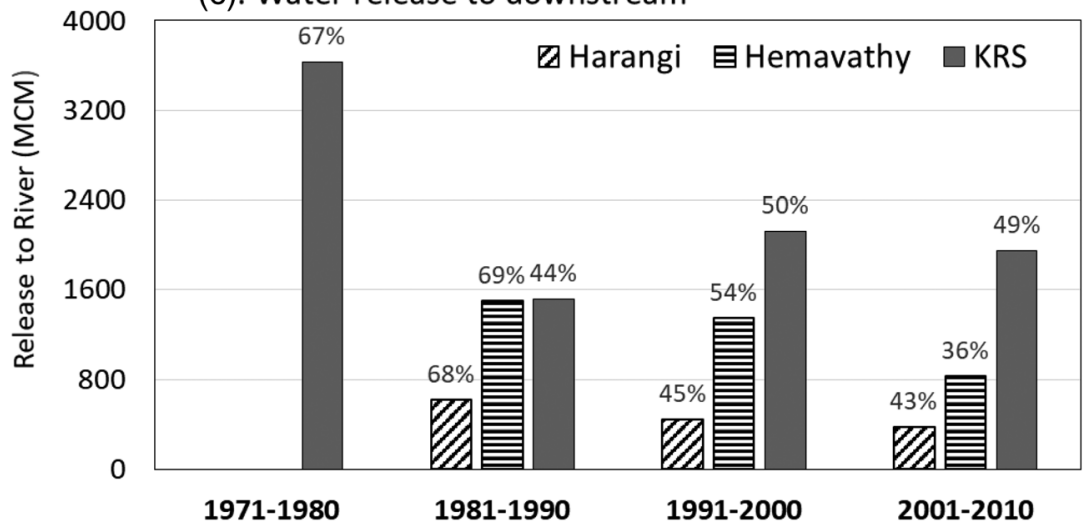

over 55\%, from $3600 \mathrm{MCM}$ in 1971-1980 to $1950 \mathrm{MCM}$ in 2001-2010. Similarly in both the upstream reservoirs (Harangi and Hemavathy), water release downstream declined from $68-69 \%$ (of total inflow) in 1981-1990 to $36-43 \%$ in $2001-2010$.

\section{3 | Model performance}

Figure 7 presents the model's performance by comparing simulated flow with observed flow data at four out of seven gauging stations of Kudige, Sakaleshpur,
Chuchunkatte and Akkihebbal and inflows into the Hemavathy and KRS reservoirs on a monthly timescale between 1981 and 2013. The flow data for Sakaleshpur, Chuchunkatte and Akkihebbal were only available for 2002-2014, 2008-2014 and 2002-2014 respectively. In general, the simulated flow at monitoring locations agreed with the observed values as well as matching the peaks. However, at Kudige gauging station (Figure 1, Figure 7(a)) and inflow at Hemavathy (Figure 1, Figure 7(f)), simulated flow was underestimated. Runoff at upstream locations is generated from the Western Ghats. It is possible that the data 

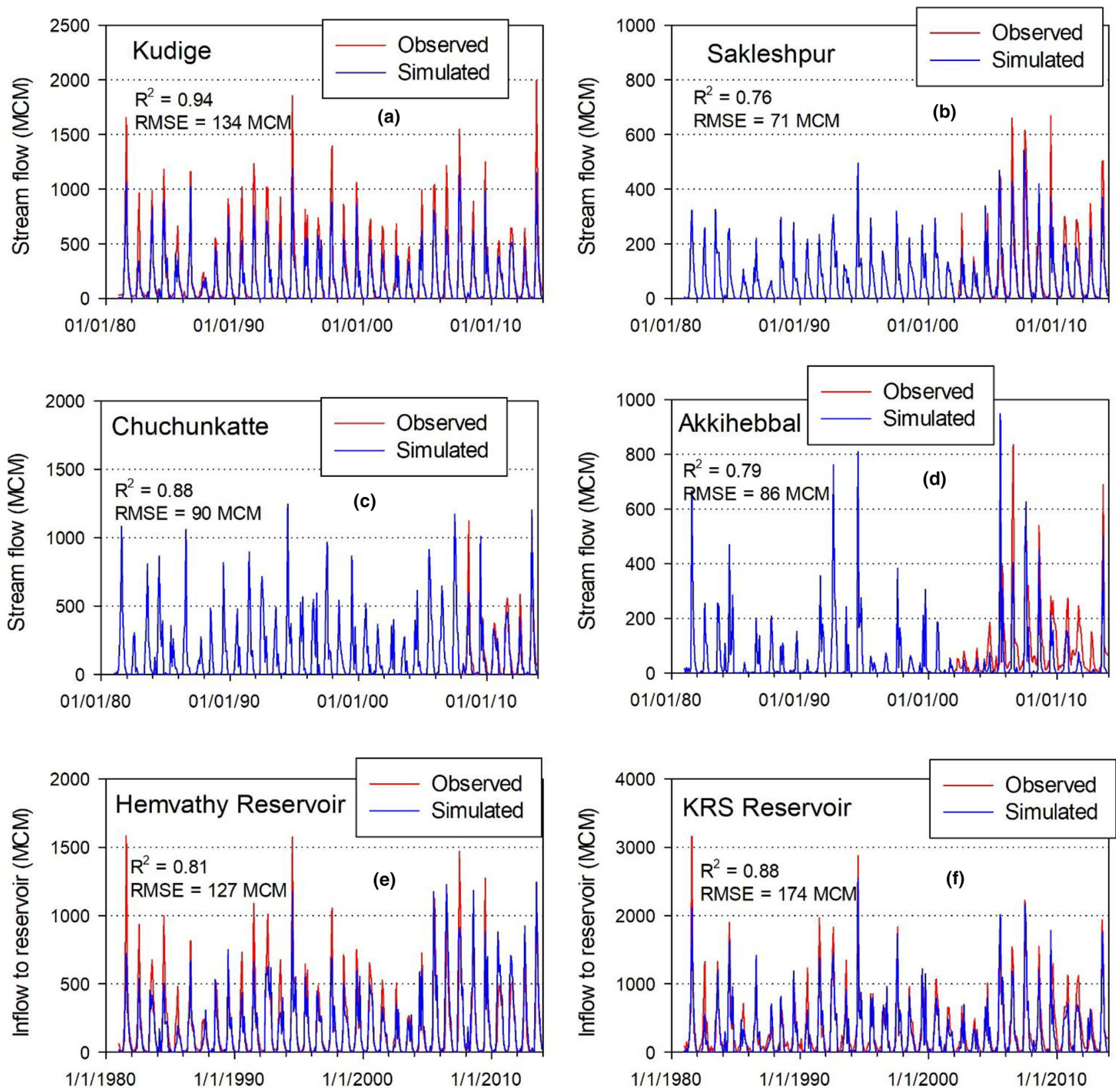

F I G U R E 7 Monthly time series of observed (red) and simulated (blue) streamflow/reservoir inflows for (a) Kudige gauge site, (b) Sakleshpur, (c) Chuchunkatte, (d) Akkihebbal, (e) Hemavathy and (f) KRS reservoir

from the rain gauges did not capture the entire rainfall variability of the Western Ghats region. There was a steep gradient of rainfall from 2000 to $5000 \mathrm{~mm}$ within a $100 \mathrm{~km}$ distance which was not captured fully due to limited rain gauge monitoring. The model's performance in simulating inflows at a monthly scale into the KRS reservoir shows that it captured the rising limb, peaks and recession limb of inflows quite well; however, the peaks were overpredicted for a few events. Model performance was further evaluated by estimating RMSE (174 MCM), NSE (0.85) and $R^{2}(0.88)$, indicating that the model was in consonance with observed data.
The model's performance statistics from all the gauging stations and reservoirs are summarized in Table 3. Out of 10 sites, $R^{2}$ was found to be more than 0.75 in eight sites, and NSE was equal to or more than 0.5 at eight sites. Overall, the model was able to capture the catchment hydrology fairly well.

\subsection{Water balance components}

Rainfall is split into major water balance components: evapotranspiration (ET), runoff and change in water 
storage. The average annual rainfall of the catchment was $1280 \mathrm{~mm}$ and varied from 880 to $1880 \mathrm{~mm}$ between 1981 and 2013. Of this, $54 \%(700 \mathrm{~mm})$ of total rainfall was split into ET $(590-800 \mathrm{~mm}), 29 \%(370 \mathrm{~mm})$ as catchment outflow $(170-630 \mathrm{~mm})$ and the remainder $17 \%$ $(215 \mathrm{~mm})$ as change in water storage (Figure 8(a)). In the current case, inflow to the KSR reservoir is considered as outflow from the catchment as KRS is located at the outlet of the catchment.

Figure 8(b) shows the water balance components for a wet (2007), normal (2008) and dry (2012) year. The annual rainfall received during wet, normal and dry years was 1690, 1400 and $1120 \mathrm{~mm}$, respectively. Most of the rainfall went towards ET, estimated to be $600-750 \mathrm{~mm}$, which is $40-60 \%$ of the total rainfall received. The surface runoff generated was $715 \mathrm{~mm}$ (42\% of rainfall) in a wet year, $450 \mathrm{~mm}$ (34\%) in a normal year and $325 \mathrm{~mm}(29 \%)$ in a dry year. The change in groundwater recharge was in the order of $130-230 \mathrm{MCM}$, of which $11-14 \%$ was generated by the rainfall received. A comparison of dry, normal and wet years showed that the most sensitive water balance component is surface runoff, followed by groundwater recharge with changing rainfall conditions from year to year.

Figure 9 shows the spatial variability in major water balance components (rainfall, ET, runoff and change in groundwater storage) for the selected wet (2007), normal (2008) and dry (2012) years across the upper Cauvery. The Western Ghats received the highest rainfall (>3000 mm), with rainfall decreasing from west to east. Spatial data showed that $40 \%$ of the catchment received less than $1000 \mathrm{~mm}$ rainfall, 35\% between 1000 and $2000 \mathrm{~mm}$, and $25 \%$ above $2000 \mathrm{~mm}$ during the normal year. The distribution changed to $40 \%$ ( $<1000 \mathrm{~mm}$ ), $40 \%$ (1000-2000 $\mathrm{mm})$ and $20 \%(>2000 \mathrm{~mm})$ in a dry year and
$45 \% \quad(<1000 \mathrm{~mm}), \quad 25 \% \quad(1000-2000 \mathrm{~mm})$ and $30 \%$ $(>2000 \mathrm{~mm})$ in a wet year.

ET varied with rainfall distribution. ET in the Western Ghats was higher than in agricultural land. A large area under forest in the Western Ghats and frequent rains generated significant ET $(\sim 700-900 \mathrm{~mm})$. In the study area, ET for about $10 \%$ of the catchment was less than $500 \mathrm{~mm}$, between 500 and $900 \mathrm{~mm}$ for $80 \%$ of the area and $>900 \mathrm{~mm}$ for $10 \%$ of the area in a dry year. In normal and wet years, ET for about $88-90 \%$ of the area was simulated to range from 500 to $900 \mathrm{~mm}$ and $>900 \mathrm{~mm}$ for $10-12 \%$ of the area of the upper Cauvery. Groundwater withdrawal in agriculture was simulated from 40 to $66 \mathrm{~mm}$ (425-700 $\mathrm{MCM}$ ) with average of $50 \mathrm{~mm}$ (i.e. $530 \mathrm{MCM}$ ). Groundwater withdrawal reported by the National Water Development Agency for the upper Cauvery catchment in 2011 was $488 \mathrm{MCM}$ (i.e. $46 \mathrm{~mm}$ ) which is in close agreement with current analysis (GoI, 2019).

Change in groundwater storage was mapped on a spatial scale for selected dry, normal and wet years. Results from the model showed a negative groundwater balance in more than $50 \%$ of the area in a dry year, as water withdrawal in these catchments had been higher than the recharge. A negative groundwater balance was found in $20 \%$ of the area in normal years and 3\% in wet years. Runoff, an important source of fresh water, was found to be the most sensitive water balance component with variable rainfall. In a dry year, more than $50 \%$ of the catchment produced less than $100 \mathrm{~mm}$ of runoff, about $25 \%$ between 100 and $500 \mathrm{~mm}$, and $25 \%$ more than $500 \mathrm{~mm}$. This proportion changed to $25 \%$ ( $<100 \mathrm{~mm}), 40 \%$ (100$500 \mathrm{~mm}$ ) and $35 \%(>500 \mathrm{~mm})$ in normal and wet years. Figure 10 shows the spatial variability in simulated runoff coefficients within the catchment. The runoff coefficient in $50 \%$ of the area was $<0.15$, and in $40 \%$ of the area

T A B L E 3 Model performance statistics to simulate monthly inflows during calibration

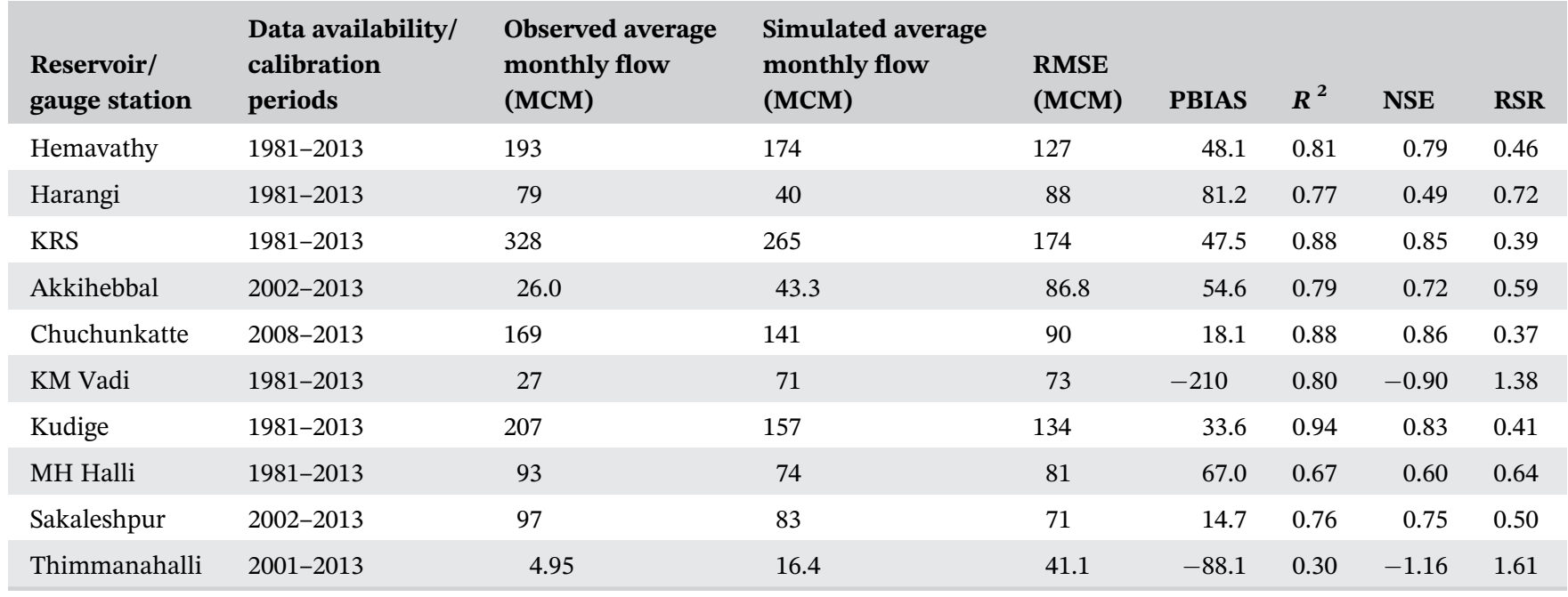



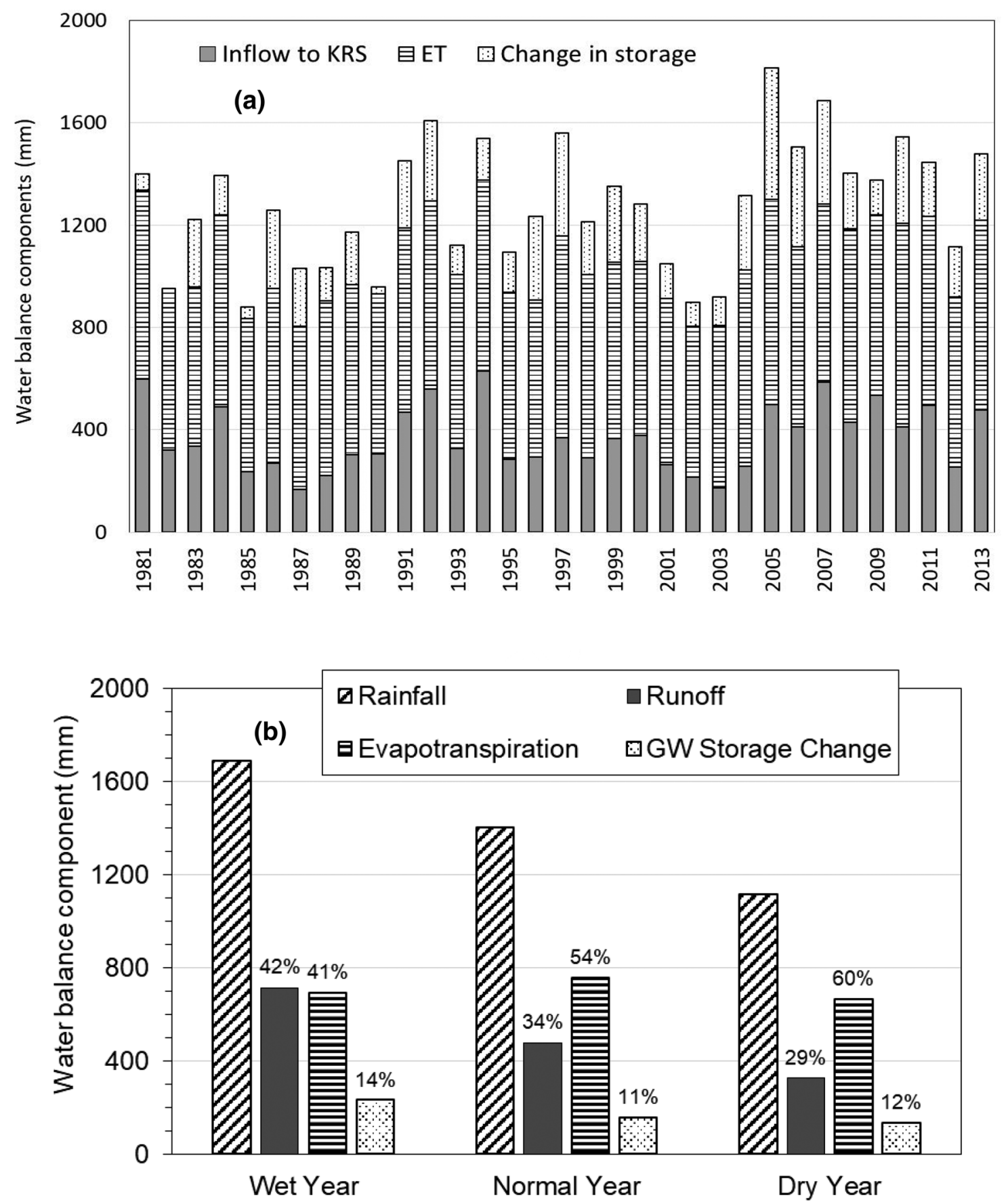

FI G URE 8 (a) Major water balance component (rainfall = outflow + ET + change in storage) of the upper Cauvery catchment between 1981 and 2013. The sum of the three components is equal to the total rainfall in respective years, (b) water balance in the upper Cauvery catchment during wet (2007), normal (2008) and dry (2012) years. (Numbers in the figure indicate the percentage rainfall in a particular year.)

$0.15-0.45$ during a dry year. The runoff coefficient in $30 \%$ of the area was $<0.15$ and in $60 \%$ of the area $0.15-0.45$. The remaining $10 \%$ of the area had more than 0.45 runoff coefficient during a normal year. The runoff coefficient for $25 \%$ of the area was less than 0.15 , for $45 \%$ of the area $0.15-0.45$ and for $30 \%$ of the area more than 0.45 in a wet year.

\subsection{Impact of AWM interventions}

Figure 11 summarizes the simulated KRS reservoir inflow under the four land management scenarios. Under the no-intervention scenario, the annual inflows during wet, normal and dry years were 7800,4300 and $3100 \mathrm{MCM}$, respectively. Under the 2020 scenario, inflows fell by 
FI G URE 9 Spatial variability in different water balance components for selected wet (2007), normal (2008) and dry (2012) years
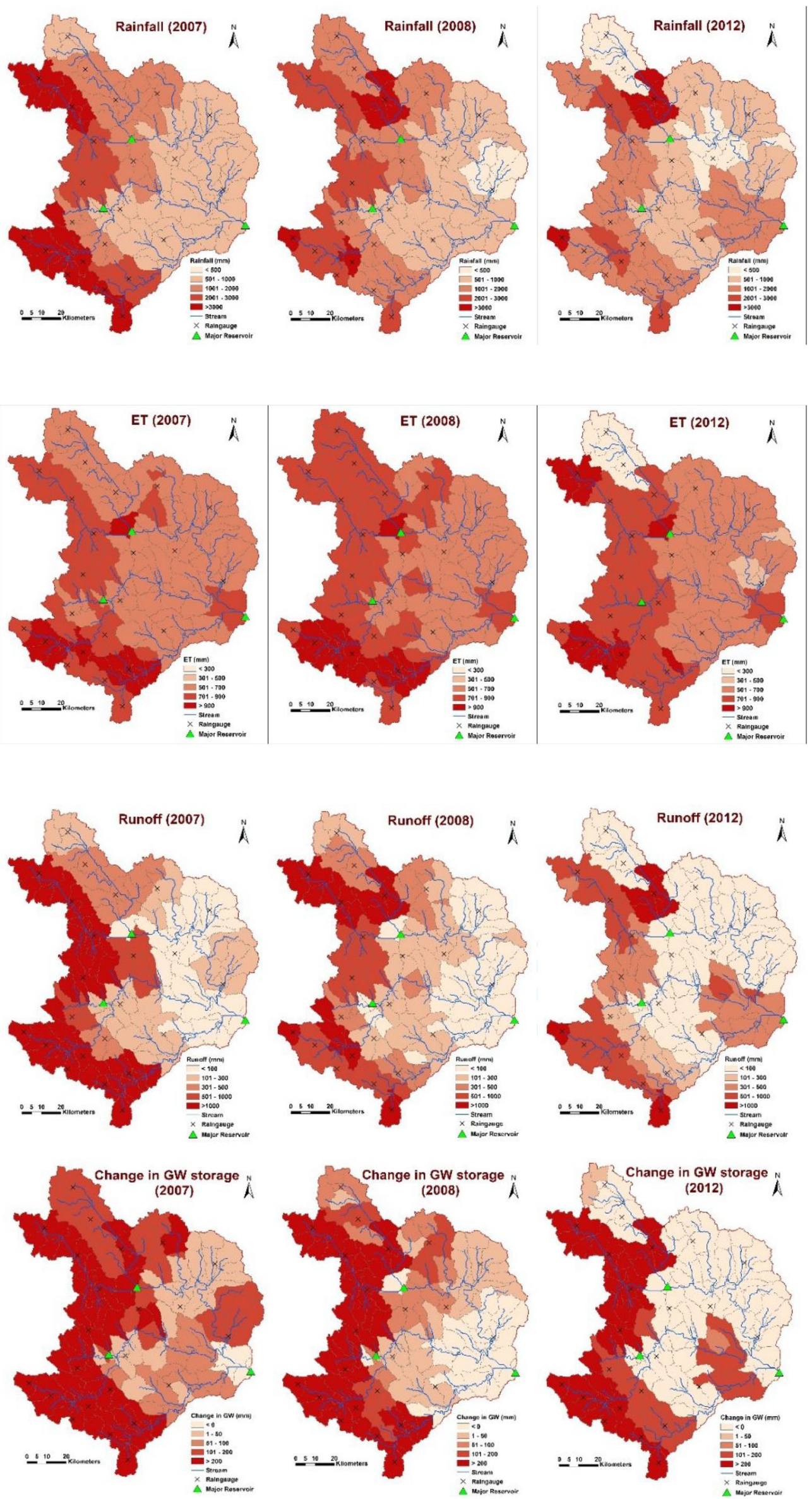

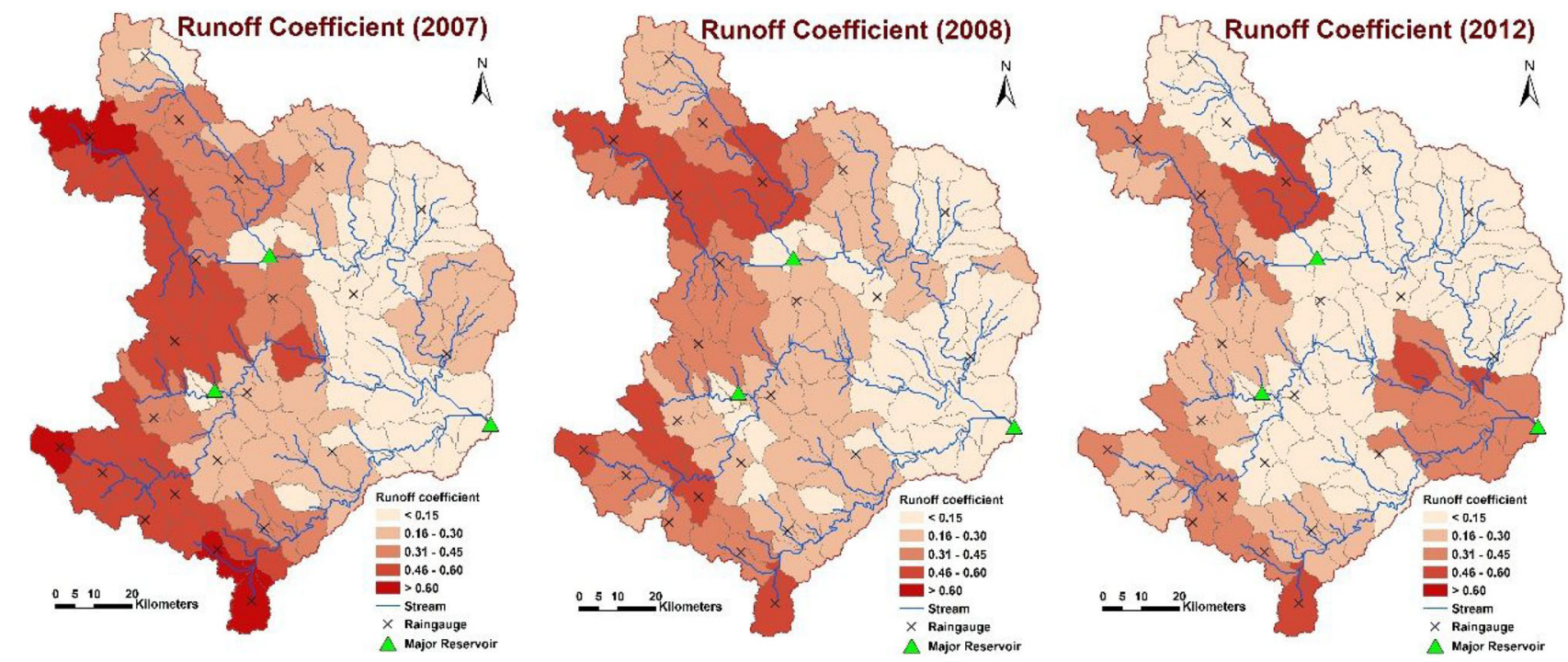

F I G U RE 10 Spatial variability in simulated runoff coefficients in different micro-catchments of the upper Cauvery catchment for selected wet (2007), normal (2008) and dry (2012) years

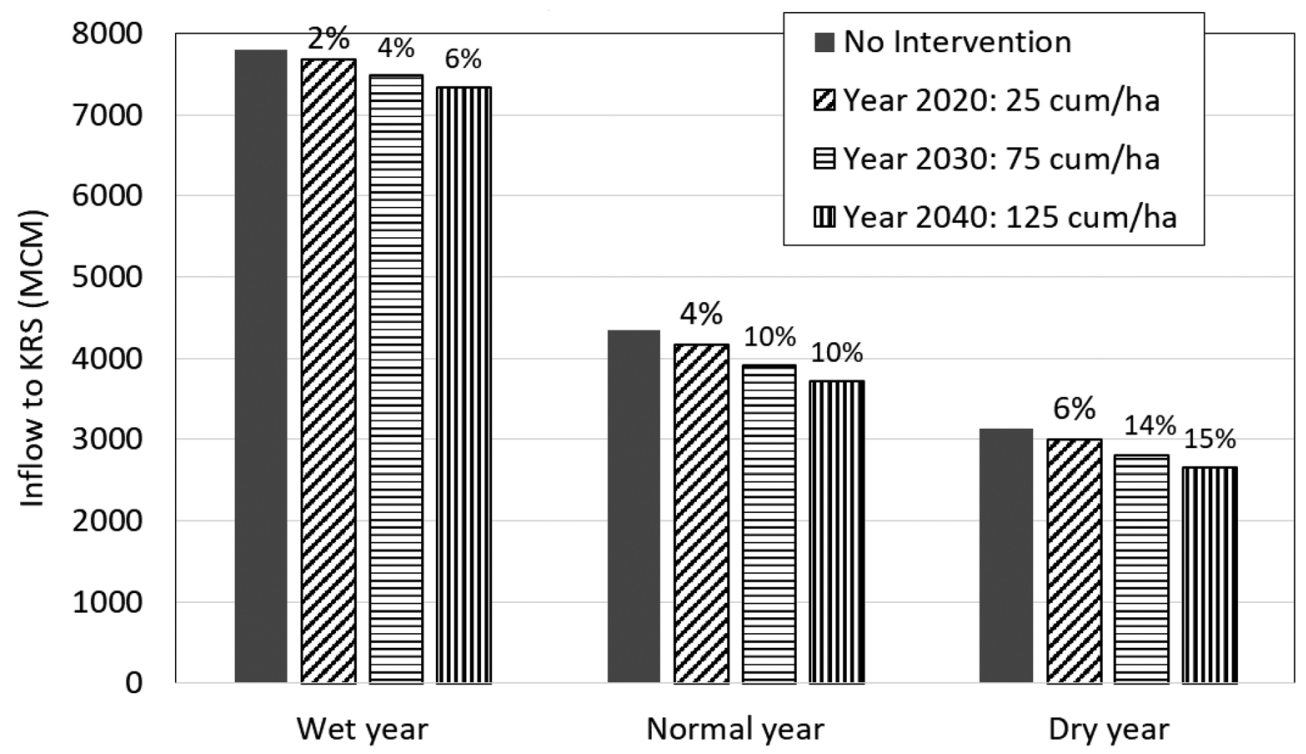

FI G U RE 11 Impact of interventions on inflows into the KRS reservoir. Label values indicates percentage decrease with respect to the nointervention scenario

2-6\% due to various water-harvesting interventions. Under the 2030 and 2040 scenarios, simulation suggested that intensifying AWM interventions would reduce KRS inflow by $6-15 \%$. Simulation suggested greater flow reduction in normal and dry years (by 10-15\%) compared to wet years (4-6\%).

Figure 12(a) compares the efficacy of AWM interventions in terms of total water harvested in upstream catchments during wet, normal and dry years and under three different land management scenarios (2020, 2030 and 2040). Under the current scenario (2020), about 140-220 $\mathrm{MCM} \mathrm{yr}^{-1}$ fresh water was harvested which is equivalent to $13-20 \mathrm{~mm}$ at catchment scale. With increased intensity of AWM interventions in 2030 and 2040, simulated results showed 300-440 $\mathrm{MCM} \mathrm{yr}^{-1}(28-41 \mathrm{~mm})$ and $460-$ $610{\mathrm{MCM} \mathrm{yr}^{-1}}^{-1}(43-57 \mathrm{~mm})$ of water harvested in upstream catchments, respectively. Simulation suggested that AWM interventions filled 8-12 times of the total storage capacity created under the current scenario. The number of fillings fell with increased density of interventions as the number of fillings in future scenarios (i.e. 2030 and 2040) was simulated to be 6-11 and 5-11 times, respectively (Figure 12(b)).

Figure 13 summarizes the water harvested in upstream catchments under dry, normal and wet years and also under 2020, 2030 and 2040 AWM scenarios. 
FI G URE 12 (a) Water harvested by in situ and ex situ interventions and (b) number of fillings during wet, normal and wet years under 2020, 2030 and 2040 land management scenarios
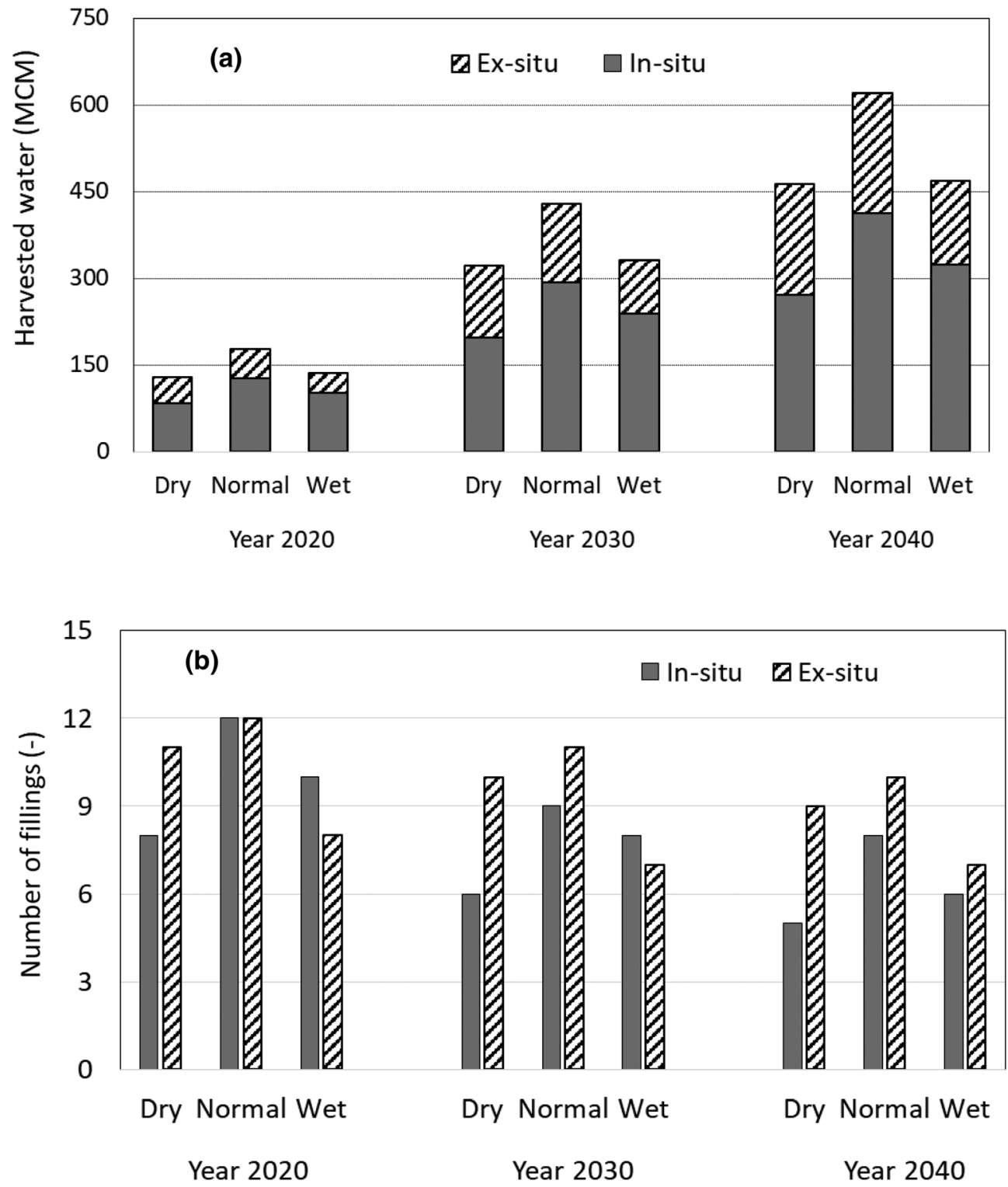

Currently (in 2020), more than $80-90 \%$ of catchments in the uplands are harvesting less than $25 \mathrm{~mm}$ runoff, including during wet years, and less than $10 \%$ of them are harvesting runoff between 25 and $100 \mathrm{~mm}$. With increased intensity of AWM interventions, simulation demonstrated that about $40-50 \%$ of the catchments would harvest runoff less than or equal to $25 \mathrm{~mm}, 20$ $30 \%$ of them would harvest between 25 and $75 \mathrm{~mm}$ and $10-20 \%$ of them would harvest more than $75 \mathrm{~mm}$ in 2030.

\subsection{Uncertainties in the model}

Though catchment hydrology is complex to model due to heterogeneity in the topography, soil types, rainfall, land use and management practices, an effort was made to do so by using secondary data and field measurements to reduce uncertainty in the results. The density of rain gauge stations is low, approximately one rain gauge for every $460 \mathrm{~km}^{2}$. This low density, especially in the Western Ghats region, may not be able to capture the rainfall's spatial variability adequately. Rainfall in the Western Ghats varies from 1000 to $5000 \mathrm{~mm}$ within a $50-100 \mathrm{~km}$ radius. We also realized that inflow modelled at upstream reservoirs was far lower than the observed data at Harangi. Within the model's set-up, we assumed a limited cropping system whereas in reality there is a multiple cropping system and associated land management. The number of AWM interventions was simplified by creating a reservoir node either of in situ or ex situ type for each catchment. This may also generate uncertainty as the responses of different AWM interventions depend on their catchment (location), type and capacity. 

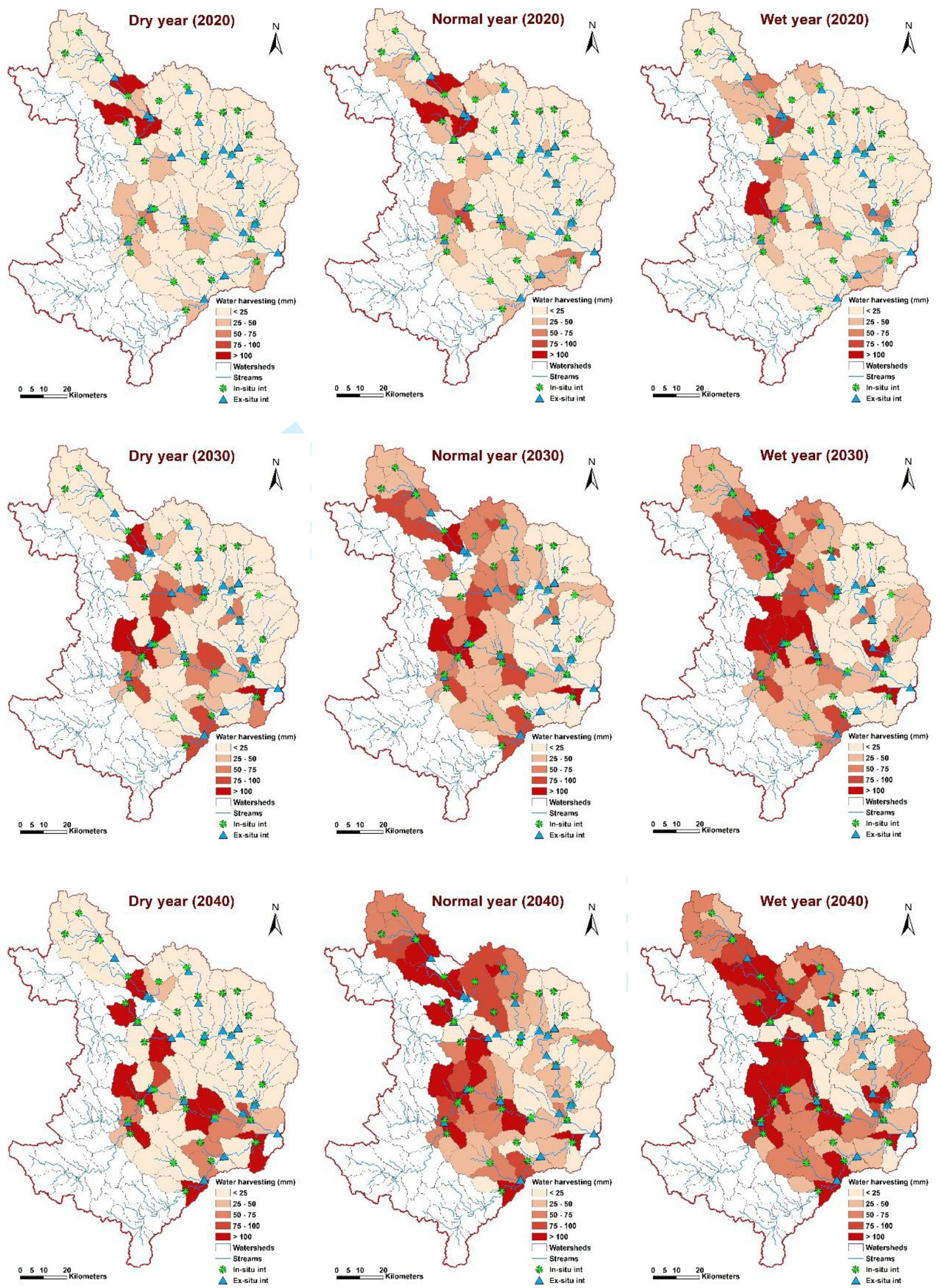

F I G U RE 13 Spatial variability of total harvested water due to various AWM interventions for 2020, 2030 and 2040 scenarios under wet (2007), normal (2008) and dry (2012) years, respectively 


\section{4 | DISCUSSION}

The study showed that a major portion of fresh water in the catchment came from the Western Ghats. The runoff coefficient of the Western Ghats was as high as $60-70 \%$. Thus, rainfall of more than $3000 \mathrm{~mm}$ generated over $2000 \mathrm{~mm}$ of runoff. Results also showed that fresh water generated from drylands was comparatively low as most of the rainfall was in the form of ET. More than $50 \%$ of the catchment, especially in dry and normal years, generated $100 \mathrm{~mm}$ runoff or less with a runoff coefficient of $15-20 \%$.

Under the current scenario (2020), AWM interventions implemented in the drylands as a drought mitigation strategy harvested $25-30 \mathrm{~mm}$ of water, while the rest was available for downstream users. However, catchment-scale water balance showed that flow reduction in the KRS reservoir due to AWM interventions was less than $6 \%$ of the total inflow generated. Runoff generated from the Western Ghats is a major contributor to the KRS reservoir (surplus from Harangi and Hemavathy reservoirs). However, the increased density of AWM interventions could be a matter of concern for command area authorities as the inflow at the KRS reservoir may decline by $6-15 \%$ by 2040 .

The results showed that water allocation in canal command areas from all three reservoirs increased at the rate of $60 \mathrm{MCM} \mathrm{yr}^{-1}$. Water release from the KRS reservoir declined from $3600 \mathrm{MCM}$ in 1971-80 to 1950 MCM in 2001-2010, indicating a 55\% reduction in the downstream part of the upper Cauvery basin. Of this, only $2-6 \%$ is due to AWM interventions and the rest due to water allocation in canal command areas. A water balance analysis showed that runoff generated from dryland areas during deficit years was relatively poor. Even under the no-intervention scenario, the runoff generated was far lower than the required demand from the canal command area. AWM interventions have, however, created a little more deficit against total freshwater demand at KRS but at the same time it might be helpful for alleviating drought in the uplands. The amount of water harvested by AWM interventions in a dry year was comparable to that in a wet year. Since AWM interventions harvest a little surface runoff from frequent events, there was not much difference in their efficacy between different rainfall years. These interventions were found to harvest runoff 8-12 times per year of its storage capacity.

AWM interventions in the drylands are meant to alleviate crop water stress by enhancing soil moisture availability, providing life-saving supplemental irrigation through locally harvested runoff, enhancing groundwater recharge and crop intensification. Our analysis showed that water harvested from AWM interventions was equivalent to one or two supplemental irrigations $(\sim 25-$ $30 \mathrm{~mm}$ ) which could be in the form of enhanced soil moisture or blue water availability depending on the local situation and management. However, the resulting gains in crop productivity and crop intensification due to such interventions were beyond the scope of this study. In this basin, there is an apparent trade-off between local benefits and downstream water availability. Upstream development brings regional equity, as the uplands mostly suffer from water scarcity, poor productivity and land degradation, whereas a little reduction in the flow at the KRS reservoir could be compensated by promoting improved water management practices.

Previous studies in semi-arid tropical central and southern India have reported altered catchment hydrology due to AWM interventions, with a reduction in runoff of $30-50 \%$ compared to no-intervention conditions. However, at the same time, these catchments have transformed the landscape. A few studies have reported that check dams and various rainwater storage structures have harvested 5-10 times the total storage capacity developed in the degraded landscapes of central and western India, with rainfall ranging from 600 to $900 \mathrm{~mm}$ (Singh et al., 2014; Garg et al., 2021). AWM interventions enhanced groundwater recharge (by 30-50\%), crop productivity (by 50-200\%), crop intensification (by 30-50\%) and controlled soil erosion and land degradation (by 7090\%) compared to the non-intervention stage (Garg et al., 2011, 2012a; Singh et al., 2014; Garg et al., 2020a; Garg et al., 2021). Garg et al. (2011) modelled the impact of various AWM interventions on hydrological processes in the Osman Sagar catchment $\left(736 \mathrm{~km}^{2}\right)$ of the Musi basin in the semi-arid tropics of southern India. The study reported that AWM interventions in the meso-scale catchment reduced inflow into the Osman Sagar reservoir by $40 \%$ but improved groundwater recharge and crop intensification by $30 \%$ and enhanced crop yields and farm incomes in upstream areas. This also reduced flow intensity and sedimentation in downstream water bodies. In the trade-off between upstream and downstream, there were more upstream benefits and relatively minor negative impacts on downstream flow.

Rainfed areas hold great untapped potential in terms of addressing food security and sustainable development goals that can be unlocked using resource conservation technologies. At the same time, irrigated agriculture has to keep productivity levels high despite reduced resource availability which, historically, used to be met from upstream sources. With developments upstream, downstream irrigated ecosystems need to enhance water use efficiency by adopting conservation measures and demand management strategies. This study's outcomes 
will help stakeholders design and prioritize development plans for better water management in the basin.

\section{5 | CONCLUSIONS}

An analysis was done of the water balance components of the upper catchment of Cauvery basin. A Soil and Water Assessment Tool (SWAT) was applied to investigate the basin's hydrology. The model was calibrated at 10 sites (7 runoff gauges and 3 reservoirs) between 1981 and 2013. The historical changes in inflow pattern, canal releases and downstream flow in all three main reservoirs were analysed using observation data sets. The model was further parameterized to quantify AWM interventions in the upstream areas. In addition, four land management scenarios representing no-intervention, current status (2020), 2030 and 2040 were generated. The key findings were as follows:

- there is increasing water allocation for agriculture in the canal command areas from the three main reservoirs. Surface water utilization for agriculture which was $1450 \mathrm{MCM} \mathrm{yr}^{-1}$ in 1971-1980 increased to 3800 MCM yr ${ }^{-1}$ in 2001-2010. The average increase in water allocation for agriculture is $60 \mathrm{MCM} \mathrm{yr}^{-1}$. The increased allocation led to a 55\% decline in water released from the KRS reservoir to the downstream river, from $3600 \mathrm{MCM} \mathrm{yr}^{-1}$ in 1971-1980 to $1950 \mathrm{MCM}$ $\mathrm{yr}^{-1}$ in 2001-2010;

- the main source of fresh water in the catchment comes from the Western Ghats region, which receives more than $3000 \mathrm{~mm}$ of rainfall. The runoff coefficient of this region was more than $60 \%$. The average annual rainfall in the basin is $1280 \mathrm{~mm}$; $29 \%$ of this generated outflow from the catchment; $54 \%$ was in the form of ET, and the remaining $17 \%$ contributed to change in soil water storage;

- more than $50 \%$ of the drylands portion of the catchment receives rainfall ranging from 700 to $1200 \mathrm{~mm}$. Most of it is in the form of ET and less than 15-20\% generates surface runoff. The change in groundwater storage in the drylands was mostly negative as groundwater withdrawal exceeded recharge most of the time;

- the model suggested that various in situ and ex situ interventions harvested surface runoff of about 140-160 MCM $\mathrm{yr}^{-1}$ under the current implementation status (which is equivalent to $13-15 \mathrm{~mm}$ ). This has reduced inflow into the KRS reservoir by less than $6 \%$. Increasing the density of AWM interventions in the future (i.e. 2030 and 2040) is expected to harvest $300-440$ MCM (28-41 mm) and 460-610
MCM (43-57 mm) of surface runoff in the uplands, respectively. This may reduce inflow into the KRS reservoir by $15 \%$ at most.

These findings are useful for stakeholders such as development agencies, water authorities, water companies, reservoir managers, decision makers, local authorities/ councils and farmers' associations to help them understand the upstream and downstream trade-offs that will enable them to take informed decisions.

\section{ACKNOWLEDGEMENTS}

The research underlying this paper was carried out under the UPSCAPE project of the Newton-Bhabha programme 'Sustaining Water Resources for Food, Energy and Ecosystem Services', funded by the UK Natural Environment Research Council (NERC-UKRI) and India's Ministry of Earth Sciences (MoES). Thanks are due to the canal command authorities for providing reservoir data. The CGIAR Research Programme-Water, Land and Ecosystem's (WLE) support for ICRISAT scientists' time for writing this manuscript is duly acknowledged.

\section{DATA AVAILABILITY STATEMENT}

Data available on request from the authors

\section{REFERENCES}

Ahmadzadeh, H., Morid, S., Delavar, M. \& Srinivasan, R. (2016) Using the SWAT model to assess the impacts of changing irrigation from surface to pressurized systems on water productivity and water saving in the Zarrineh Rud catchment. Agricultural Water Management, 175, 15-28. https://doi.org/10. 1016/j.agwat.2015.10.026

Anand, J., Gosain, A.K. \& Khosa, R. (2018) Optimisation of multipurpose reservoir operation by coupling Soil and Water Assessment Tool (SWAT) and genetic algorithm for optimal operating policy (Case Study: Ganga River Basin). Sustainability, 10(5), 1660. https://doi.org/10.3390/su10051660

Anantha, K.H., Garg, K.K., Cameron, A.P. \& Dixit, S. (2021a) Seeking sustainable pathways for fostering agricultural transformation in Peninsular India. Environmental Research Letters, 16(4), 044032. https://doi.org/10.1088/1748-9326/abed7b

Anantha, K.H., Garg, K.K., Moses, S.D., Patil, M.D., Sawargaonkar, G.L., Kamdi, P.J. et al. (2021b) Impact of natural resource management interventions on water resources and environmental services in different agroecological regions of India. Groundwater for Sustainable Development, 13, 100574. https://doi.org/10.1016/j.gsd.2021.100574

Arnold, J.G., Moriasi, D.N., Gassman, P.W., Abbaspour, K.C., White, M.J., Srinivasan, R. et al. (2012) SWAT: model use, calibration, and validation. Transactions of the ASABE, 55, 1491-1508.

Batchelor, C.H., Rama Mohan Rao, M.S. \& Manohar Rao, S. (2003) Watershed development: A solution to water shortages in semiarid India or part of the problem? Land Use and Water Resources Research, 3, 1-10. 
Berihun, M.L., Tsunekawa, A., Haregeweyn, N., Dile, Y.T., Tsubo, M., Fenta, A.A. et al. (2020) Evaluating runoff and sediment responses to soil and water conservation practices by employing alternative modeling approaches. Science of the Total Environment, 747, 141118. https://doi.org/10.1016/j.scitotenv. 2020.141118

Betrie, G.D., Mohamed, Y.A., Van Griensven, A. \& Srinivasan, R. (2011) Sediment management modelling in the Blue Nile Basin using SWAT model. Hydrology and Earth System Sciences, 15(3), 807-818. https://doi.org/10.5194/hess-15-8072011

Bhanja, S.N. \& Mukherjee, A. (2019) In-situ and satellite-based estimates of usable groundwater storage across India: Implications for drinking water supply and food security. Advances in Water Resources, 126, 15-23. https://doi.org/10.1016/j.advwatres.2019. 02.001

Bhattacharyya, R., Ghosh, B.N., Dogra, P., Mishra, P.K., Santra, P., Kumar, S. et al. (2016) Soil conservation issues in India. Sustainability, 8(6), 565. https://doi.org/10.3390/su8060565

Bhave, A.G., Conway, D., Dessai, S. \& Stainforth, D.A. (2018) Water resource planning under future climate and socioeconomic uncertainty in the Cauvery River Basin in Karnataka, India. Water Resources Research, 54(2), 708-728. https://doi.org/10. 1002/2017WR020970

Bouma, J.A., Biggs, T.W. \& Bouwer, L.M. (2011) The downstream externalities of harvesting rainwater in semi-arid watersheds: An Indian case study. Agricultural Water Management, 98(7), 1162-1170. https://doi.org/10.1016/j.agwat.2011.02.010

Chen, Y., Marek, G.W., Marek, T.H., Porter, D.O., Moorhead, J.E., Heflin, K.R. et al. (2020) Watershed scale evaluation of an improved SWAT auto-irrigation function. Environmental Modelling \& Software, 131, 104789. https://doi.org/10.1016/j. envsoft.2020.104789

Deshingkar, P. (2012) Environmental risk, resilience and migration: implications for natural resource management and agriculture. Environmental Research Letters, 7(1), 015603. https://doi.org/ 10.1088/1748-9326/7/1/015603

Dile, Y., Berndtsson, R. \& Setegn, S.G. (2013) Hydrological response to climate change for Gilgel Abay River, in the Lake Tana Basin - upper Blue Nile Basin of Ethiopia. PLOS ONE, 8(10), 12-17. https://doi.org/10.1371/journal.pone.0079296

Dile, Y., Srinivasan, R. \& Karlberg, L. (2016a) Assessing the implications of water harvesting intensification on upstreamdownstream social-ecological resilience: a case study in the Lake Tana Basin. Science of the Total Environment, 542, 22-35. https://doi.org/10.1016/j.scitotenv.2015.10.065

Dile, Y.T., Karlberg, L., Daggupati, P., Srinivasan, R., Wiberg, D. \& Rockström, J. (2016b) Assessing the implications of water harvesting intensification on upstream-downstream ecosystem services: A case study in the Lake Tana basin. Science of the Total Environment, 542, 22-35. https://doi.org/10.1016/j. scitotenv.2015.10.065

Ferdin, M., Görlitz, S. \& Schwörer, S. (2010) Water stress in the Cauvery basin, south India. How current water management approaches and allocation conflict constrain reform. ASIEN: German Journal for Politics, Economy and Culture, 117, 27-44.

Fischer, R.A. (2015) Definitions and determination of crop yield, yield gaps, and of rates of change. Field Crops Research, 182, 9-18. https://doi.org/10.1016/j.fcr.2014.12.006
Fischer, R.A. \& Connor, D.J. (2018) Issues for cropping and agricultural science in the next 20 years. Field Crops Research, 222, 121-142. https://doi.org/10.1016/j.fcr.2018.03.008

Garg, K.K., Anantha, K.H., Nune, R., Akuraju, V.R., Singh, P., Gumma, M.K. et al. (2020b) Impact of land use changes and management practices on groundwater resources in Kolar district, Southern India. Journal of Hydrology: Regional Studies, 31, 100732. https://doi.org/10.1016/j.ejrh.2020.100732

Garg, K.K., Anantha, K.H., Venkataradha, A., Dixit, S., Singh, R. \& Ragab, R. (2021) Impact of rainwater harvesting on hydrological processes in a fragile watershed of South Asia. Groundwater, 59, 839-855. https://doi.org/10.1111/gwat.13099

Garg, K.K., Bharati, L., Gaur, A., George, B., Acharya, S., Jella, K. \& Narasimhan, B. (2012b) Spatial mapping of agricultural water productivity using the SWAT model in Upper Bhima Catchment, India. Irrigation and Drainage, 61(1), 60-79. https://doi. org/10.1002/ird.618

Garg, K.K., Karlberg, L., Barron, J., Wani, S.P. \& Rockstrom, J. (2011) Assessing impacts of agricultural water interventions in the Kothapally watershed, Southern India. Hydrological Processes, 26(3), 387-404.

Garg, K.K., Singh, R., Anantha, K.H., Singh, A.K., Venkataradha, A., Barron, J. et al. (2020a) Impact of agricultural water management interventions on hydrological processes, crop intensification and agricultural productivity: A study in a meso-scale watershed, Bundelkhand region, Central India. Journal of Hydrology, 591, 125592. https://doi.org/10. 1016/j.jhydrol.2020.125592

Garg, K.K., Wani, S.P., Barron, J., Karlberg, L. \& Rockstrom, J. (2012a) Up-scaling potential impacts on water flows from agricultural water interventions: opportunities and trade-offs in the Osman Sagar catchment, Musi sub-basin, India. Hydrological Processes, 27(26), 3905-3921. https://doi.org/10.1002/hyp.9516

Gentine, P., Troy, T.J., Lintner, B.R. \& Findell, K.L. (2012) Scaling in surface hydrology: Progress and challenges. Journal of Contemporary Water Research \& Education, 147(1), 28-40. https:// doi.org/10.1111/j.1936-704X.2012.03105.x

Glavan, M. \& Pintar, M. (2012) Strengths, weaknesses, opportunities and threats of catchment modelling with soil and water assessment tool (SWAT) model. In: Nayak, P. (Ed.) Water Resources Management and Modeling. Rijeka, Croatia: InTech. ISBN: 978-953-51-0246-5

Glendenning, C.J. \& Vervoort, R.W. (2010) Hydrological impacts of rainwater harvesting $(\mathrm{RWH})$ in a case study catchment: The Arvari River, Rajasthan, India. Part 1: Field-scale impacts. Agricultural Water Management, 98(2), 331-342. https://doi.org/10. 1016/j.agwat.2010.09.003

Government of India. (2015) Statistical year book, India, 2015. New Delhi, India: Ministry of statistics and program implementation.

Government of India (GoI). (2018) Statistical abstract of India, Ministry of Agriculture and Farmers Welfare. New Delhi, India: Government of India.

Government of Karnataka. (2014) Krushi Bhagya scheme. Department of Agriculture, Government of Karnataka, Bengaluru (krushi Bhagya - Department of Agriculture (KSDA) (karnataka.gov.in).

Goyal, M.K. \& Surampalli, R.Y. (2018) Impact of climate change on water resources in India. Journal of Environmental Engineering, 
144(7), 04018054. https://doi.org/10.1061/(ASCE)EE.1943-7870. 0001394

Green, A.S., Dixit, S., Garg, K.K., Sandya, N.R., Singh, G., Vatta, K. et al. (2020) An interdisciplinary framework for using archaeology, history and collective action to enhance India's agricultural resilience and sustainability. Environmental Research Letters, 15(10), 105021. https://doi.org/10.1088/1748-9326/ aba780

Gupta, A., Himanshu, S.K., Gupta, S. \& Singh, R. (2020) Evaluation of the SWAT Model for Analysing the Water Balance Components for the Upper Sabarmati Basin. In: Advances in Water Resources Engineering and Management. Singapore: Springer, pp. 141-151.

Hao, B., Xue, Q., Marek, T.H., Jessup, K.E., Hou, X., Xu, W. et al. (2015) Soil water extraction, water use, and grain yield by drought-tolerant maize on the Texas High Plains. Agricultural Water Management, 155, 11-21. https://doi.org/10.1016/j. agwat.2015.03.007

Heller, E., Rhemtulla, J.M., Lele, S., Kalacska, M., Badiger, S., Sengupta, R. \& Ramankutty, N. (2012) Mapping crop types, irrigated areas, and cropping intensities in heterogeneous landscapes of Southern India using multi-temporal mediumresolution imagery. Photogrammetric Engineering and Remote Sensing, 78(8), 815-827. https://doi.org/10.14358/PERS.78.8.815

Hoekstra, A.Y., Mekonnen, M.M., Chapagain, A.K., Mathews, R. E. \& Richter, B.D. (2012) Global monthly water scarcity: blue water footprints versus blue water availability. PLoS ONE, 7(2), e32688. https://doi.org/10.1371/journal.pone.0032688

Horan, R., Gowri, R., Wable, P.S., Baron, H., Keller, V.D.J., Garg, K.K. et al. (2021) A comparative assessment of hydrological models in the Upper Cauvery catchment. Water, 13(2), 151. https://doi.org/10.3390/w13020151

Huang, M. \& Zhang, L. (2004) Hydrological responses to conservation practices in a catchment of the Loess Plateau, China. Hydrological Processes, 18(10), 1885-1898. https://doi.org/10. 1002/hyp.1454

India-WRIS WebGIS. (2014) Cauvery Basin report. Generation of database and implementation of web enabled water resources information system in the country (India-WRIS WebGIS), Ministry of Water Resources, Government of India. New Delhi, India.

Jain, S.K., Agarwal, P.K. \& Singh, V.P. (2007) Hydrology and water resources of India. Dordrecht, the Netherlands 1258: Springer.

Jayne, T.S., Yamano, T. \& Nyoro, J. (2004) Interlinked credit and farm intensification: evidence from Kenya. Agricultural Economics, 31(2-3), 209-218. https://doi.org/10.1111/j.1574-0862. 2004.tb00258.x

Jodar-Abellan, A., Valdes-Abellan, J., Pla, C. \& Gomariz-Castillo, F. (2019) Impact of land use changes on flash flood prediction using a sub-daily SWAT model in five Mediterranean ungauged watersheds (SE Spain). Science of the Total Environment, 657, 1578-1591. https://doi.org/10.1016/j.scitotenv.2018.12.034

Krishnan, S. \& Balakrishnan, A. (2012) Impact of watershed works of MGNREGS on poverty alleviation - a micro-level study. Indian Streams Research Journal, 2(7), 2230-7850.

Krysanova, V. \& White, M. (2015) Advances in water resources assessment with SWAT - an overview. Hydrological Sciences Journal, 60(5), 771-783. https://doi.org/10.1080/02626667.2015. 1029482
Lee, S., Yeo, I.Y., Lang, M.W., Sadeghi, A.M., McCarty, G.W., Moglen, G.E. \& Evenson, G.R. (2018) Assessing the cumulative impacts of geographically isolated wetlands on watershed hydrology using the SWAT model coupled with improved wetland modules. Journal of Environmental Management, 223, 37-48. https://doi.org/10.1016/j.jenvman.2018.06.006

Lodha, P.P. \& Gosain, A.K. (2007) Externalities in watershed management. Changes in water resources systems: methodologies to maintain water security and ensure integrated management, Proceedings of Symposium HS3006 at IUGG2007, July 2007. IAHS Publ. 315. Perugia, Italy.

Marin, M., Clinciu, I., Tudose, N.C., Ungurean, C., Adorjani, A., Mihalache, A.L. \& Cacovean, H. (2020) Assessing the vulnerability of water resources in the context of climate changes in a small forested watershed using SWAT: A review. Environmental Research, 184, 109330. https://doi.org/10.1016/j.envres.2020. 109330

Masih, I., Maskey, S., Uhlenbrook, S. \& Smakhtin, V. (2011) Impact of upstream changes in rain-fed agriculture on downstream flow in a semi-arid basin. Agricultural Water Management, 100(1), 36-45. https://doi.org/10.1016/j.agwat.2011.08.013

Mekonen, K. \& Tesfahunegn, G.B. (2011) Impact assessment of soil and water conservation measures at Medego watershed in Tigray, northern Ethiopia. Maejo International Journal of Science and Technology, 5(3), 312.

Mekonnen, D.F., Duan, Z., Rientjes, T. \& Disse, M. (2018) Analysis of combined and isolated effects of land-use and land-cover changes and climate change on the upper Blue Nile River basin's streamflow. Hydrology and Earth System Sciences, 22(12), 6187-6207. https://doi.org/10.5194/hess-22-6187-2018

Mondal, B., Loganandhan, N., Patil, S.L., Raizada, A., Kumar, S. \& Bagdi, G.L. (2020) Institutional performance and participatory paradigms: Comparing two groups of watersheds in semi-arid region of India. International Soil and Water Conservation Research, 8(2), 164-172. https://doi.org/10.1016/j.iswcr.2020. 04.002

Narsimlu, B., Gosain, A.K. \& Chahar, B.R. (2013) Assessment of future climate change impacts on water resources of Upper Sind River Basin, India using SWAT model. Water Resources Management, 27(10), 3647-3662. https://doi.org/10.1007/ s11269-013-0371-7

NITI Aayog. (2017) Road map of Pradhan Mantri Krishi Sinchayee Yojna. Niti Aayog, Government of India. New Delhi, India.

NITI Aayog. (2019) Composite water management index. Niti Aayog, Government of India. New Delhi, India.

NWDA \& Government of India (2019) Water balance study of the Upper Cauvery Sub-basin of the Cauvery Basin. Technical study number. 47, New Delhi, India: National Water Development Agency (NWDA), Government of India, pp. 1:130.

Nyssen, J., Clymans, W., Poesen, J., Vandecasteele, I., De Baets, S., Haregeweyn, N. \& Deckers, J. (2009) How soil conservation affects the catchment sediment budget-a comprehensive study in the north Ethiopian highlands. Earth Surface Processes and Landforms, 34(9), 1216-1233. https://doi.org/10.1002/esp.1805

Pellegrini, P. \& Fernández, R.J. (2018) Crop intensification, land use, and on-farm energy-use efficiency during the worldwide spread of the green revolution. Proceedings of the National Academy of Sciences, 115(10), 2335-2340. https://doi.org/10. 1073/pnas.1717072115 
Rao, C.S., Lal, R., Prasad, J., Gopinath, K.A., Singh, R., Jakkula, V.S. et al. (2015) Potential challenges of rainfed farming in India. Advances in Agronomy, 133, 113-181. https:// doi.org/10.1016/bs.agron.2015.05.004

Rockstrom, J., Falkenmark, M., Karlberg, L., Hoff, H., Rost, S. \& Gerten, D. (2009) Future water availability for global food production: the potential of green water for increasing resilience to global change. Water Resources Research, 45(7), W00A12. https://doi.org/10.1029/2007WR006767

Shiferaw, B., Reddy, V.R. \& Wani, S.P. (2008) Watershed externalities, shifting cropping patterns and groundwater depletion in Indian semi-arid villages: The effect of alternative water pricing policies. Ecological Economics, 67(2), 327-340. https://doi.org/ 10.1016/j.ecolecon.2008.05.011

Singh, R., Garg, K.K., Wani, S.P., Tewari, R.K. \& Dhyani, S.K. (2014) Impact of water management interventions on hydrology and ecosystem services in Garhkundar-Dabar watershed of Bundelkhand region, Central India. Journal of Hydrology, 509, 132-149. https://doi.org/10.1016/j.jhydrol.2013.11.030

Sood, A. \& Mathukumalli, B.K.P. (2011) Managing international river basins: reviewing India-Bangladesh transboundary water issues. International Journal of River Basin Management, 9(1), 43-52. https://doi.org/10.1080/15715124.2011.553832

Sreelash, K., Mathew, M.M., Nisha, N., Arulbalaji, P., Bindu, A. G. \& Sharma, R.K. (2020) Changes in the Hydrological Characteristics of Cauvery River draining the eastern side of southern Western Ghats, India. International Journal of River Basin Management, 18(2), 1-14. https://doi.org/10.1080/15715124. 2020.1719119

Sultan, D., Tsunekawa, A., Haregeweyn, N., Adgo, E., Tsubo, M., Meshesha, D.T. et al. (2018) Impact of soil and water conservation interventions on watershed runoff response in a tropical humid highland of Ethiopia. Environmental Management, 61(5), 860-874. https://doi.org/10.1007/s00267-0181005-x

Thokal, R.T., Gorantiwar, S.D., Kothari, M., Bhakar, S.R. \& Nandwana, B.P. (2015) Spatial Mapping of Agricultural Water Productivity Using the SWAT Model. Journal of the Institution of Engineers (India): Series a, 96(1), 85-98. https://doi.org/10. 1007/s40030-015-0113-3

Tilt, B., Braun, Y. \& He, D. (2009) Social impacts of large dam projects: A comparison of international case studies and implications for best practice. Journal of Environmental Management, 90, S249-S257. https://doi.org/10.1016/j.jenvman.2008.07.030

Tiwari, R., Somashekhar, H.I., Parama, V.R., Murthy, I.K., Kumar, M.S.M., Kumar, B.K.M. et al. (2011) MGNREGA for Environmental Service Enhancement and Vulnerability Reduction: Rapid Appraisal in Chitradurga District, Karnataka. Economic \& Political Weekly, 46(20), 39-47.

UNEP-DHI Centre on Water and Environment. (2016) Transboundary river basins: status and trends. Nairobi, Kenya.

Uniyal, B., Jha, M.K. \& Verma, A.K. (2015) Assessing climate change impact on water balance components of a river basin using SWAT model. Water Resources Management, 29(13), 4767-4785. https://doi.org/10.1007/s11269-015-1089-5

Vinogradov, Y.B., Semenova, O.M. \& Vinogradova, T.A. (2011) An approach to the scaling problem in hydrological modelling: the deterministic modelling hydrological system. Hydrological Processes, 25(7), 1055-1073. https://doi.org/10.1002/hyp.7901
Vories, E., Rhine, M. \& Straatmann, Z. (2017) Investigating irrigation scheduling for rice using variable rate irrigation. Agricultural Water Management, 179, 314-323. https://doi.org/10. 1016/j.agwat.2016.05.032

Wani, S.P., Anantha, K.H. \& Garg, K.K. (2017) Soil properties, crop yield and economics under integrated crop management practices in Karnataka, Southern India. World Development, 93, 43-61. https://doi.org/10.1016/j.worlddev.2016.12.012

Wani, S.P., Anantha, K.H., Sreedevi, T.K., Sudi, R., Singh, S.N. \& D'Souza, M. (2011) Assessing the environmental benefits of watershed development: evidence from the Indian semi-arid tropics. Journal of Sustainable Watershed Science \& Management, 1(1), 10-20. https://doi.org/10.5147/jswsm.2011.0036

Weinthal, E., Zawahri, N. \& Sowers, J. (2015) Securitizing water, climate, and migration in Israel, Jordan, and Syria. International Environmental Agreements: Politics, Law and Economics, 15(3), 293-307. https://doi.org/10.1007/s10784-015-9279-4

Whitehead, P.G., Jin, L., Macadam, I., Janes, T., Sarkar, S., Rodda, H.J.E. et al. (2018) Modelling impacts of climate change and socio-economic change on the Ganga, Brahmaputra, Meghna, Hooghly and Mahanadi river systems in India and Bangladesh. Science of the Total Environment, 636, 1362-1372. https://doi.org/10.1016/j.scitotenv.2018.04.362

Woldesenbet, T.A., Elagib, N.A., Ribbe, L. \& Heinrich, J. (2017) Hydrological responses to land use/cover changes in the source region of the upper Blue Nile Basin, Ethiopia. Science of the Total Environment, 575, 724-741. https://doi.org/10.1016/j. scitotenv.2016.09.124

Woldesenbet, T.A., Elagib, N.A., Ribbe, L. \& Heinrich, J. (2018) Catchment response to climate and land use changes in the upper Blue Nile sub-basins, Ethiopia. Science of the Total Environment, 644, 193-206. https://doi.org/10.1016/j.scitotenv.2018. 06.198

Worku, T., Khare, D. \& Tripathi, S.K. (2017) Modeling runoffsediment response to land use/land cover changes using integrated GIS and SWAT model in the Beressa watershed. Environment and Earth Science, 76(16), 1-14. https://doi.org/ 10.1007/s12665-017-6883-3

Wu, Y. \& Chen, J. (2012) An operation-based scheme for a multiyear and multipurpose reservoir to enhance macroscale hydrologic models. Journal of Hydrometeorology, 13(1), 270-283. https://doi.org/10.1175/JHM-D-10-05028.1

Zégre, N., Skaugset, A.E., Som, N.A., McDonnell, J.J. \& Ganio, L.M. (2010) In lieu of the paired catchment approach: Hydrologic model change detection at the catchment scale. Water Resources Research, 46(11), W11544. https://doi.org/10.1029/ 2009WR008601

How to cite this article: Wable, P.S., Garg, K.K., Nune, R., Venkataradha, A., KH, A., Srinivasan, V. et al. (2021) Impact of agricultural water management interventions on upstreamdownstream trade-offs in the upper Cauvery catchment, southern India: a modelling study. Irrigation and Drainage, 1-23. Available from: https://doi.org/10.1002/ird.2662 